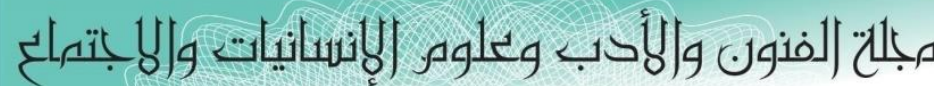

Journal of Arts, Literature, Humanities and Social Sciences

ISSN online: 2414 - 3383

ISSN print: 2616 - 3810

العدد (42) ايلول - سبتمبر 2019

\title{
دور برنامج الإنستقرام في دعم المشروعات الصغيرة للأسر المنتجة
}

\author{
د. عفاف عبد الله حسن قبوري

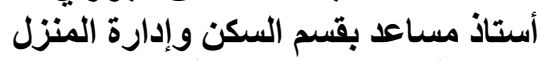

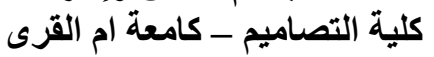 \\ المملكة العربية السعودية المبرى
}

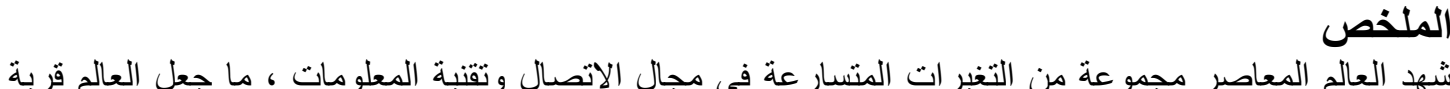

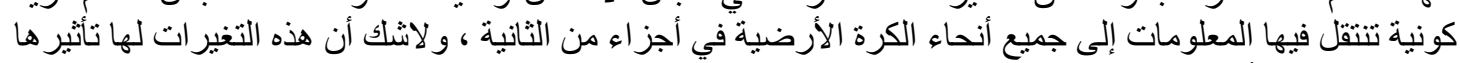

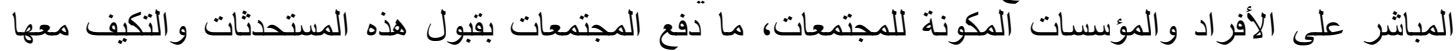

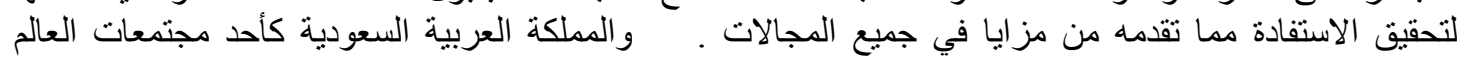

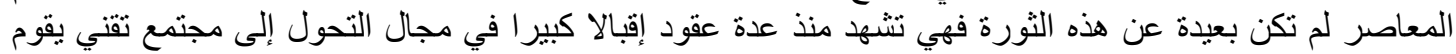

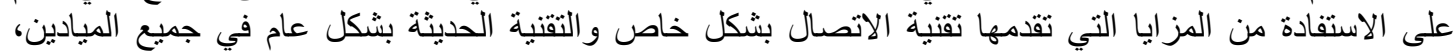

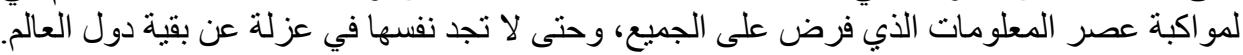

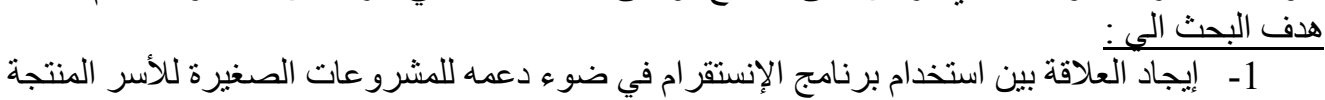

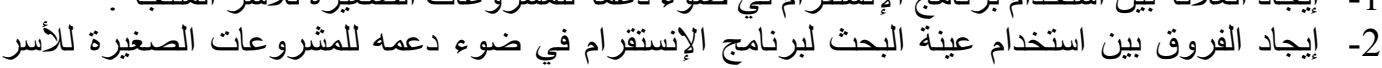

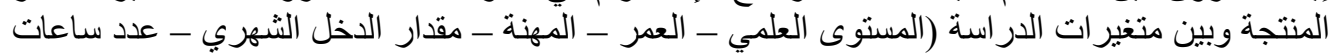
الاستخدام - طريقة الاستخدام - مجالات الاستخدة الاستخدام).

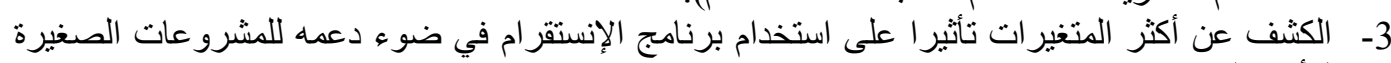

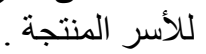
4- الكثف عن أكثرّ المتغير ات تأثثرًا على نجاح المشروعات الصغيرة للأسر المنتجة لعينة البحث. توصل البحث الي :

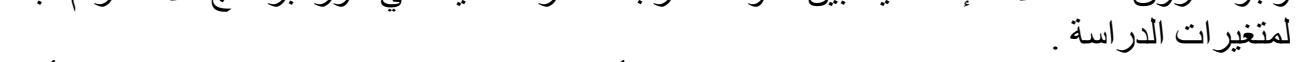
2- وجود فروق ذات دلالة إحصائية بين منوسط درجات أفر اد العينة في إدارة الششروعات الصغيرة للأسر

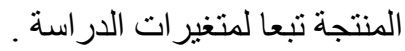

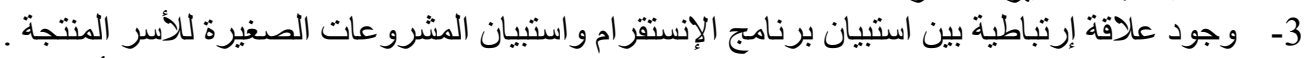

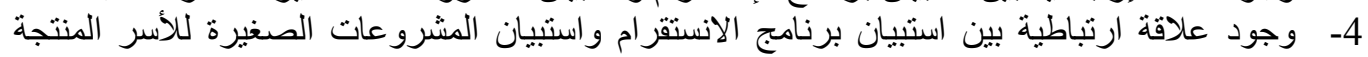

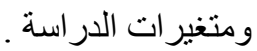

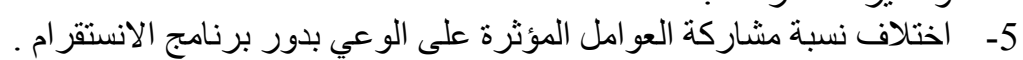

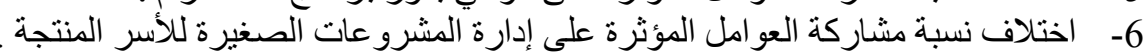

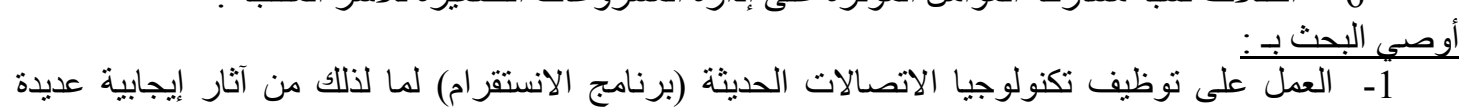

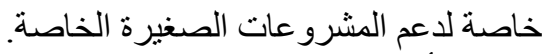

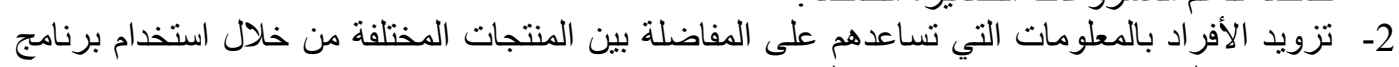

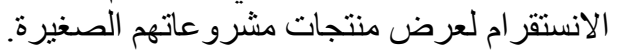

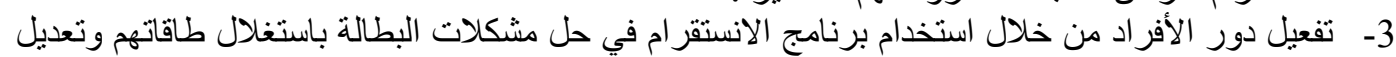

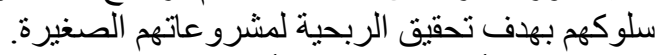

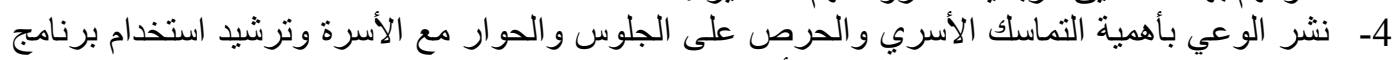
الانستقر ام حتى لا يؤثر على التو اصل مع الأسرة. 


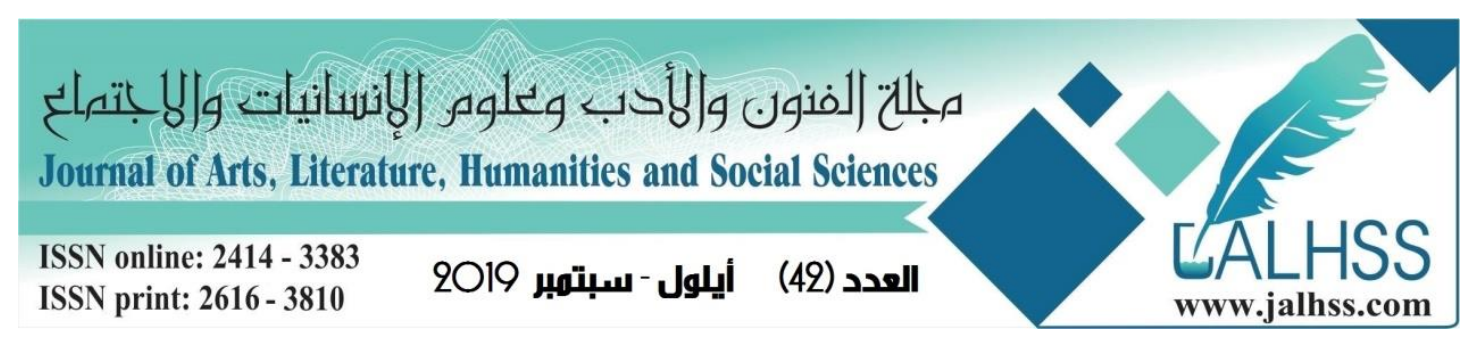

\title{
The Role of the Instagram Program in Supporting Small Projects for Productive Families
}

\begin{abstract}
The modern world has witnessed a series of rapid changes in the field of communication and information technology, making the world a global village where information is transmitted throughout the globe in parts of a second. These changes have a direct impact on the individuals and institutions of societies, prompting communities to accept these innovations And adapt to make use of its advantages in all areas.

Saudi Arabia, as one of the societies of the modern world, was not far from this revolution. For decades, it has witnessed a great turnaround in the transformation of a technical society based on the advantages of communication technology in particular and of modern technology in general in all fields, To everyone, so as not to find themselves in isolation from the rest of the world.

The research aims to:

1. Establishing the relationship between the use of the Instagram program in light of its support for small projects for productive families.

2- Finding the differences between the use of the research sample for the Instagram program in light of its support for the small projects of the productive families and the variables of the study (scientific level, age, profession, amount of monthly income, hours of use, usage method, areas of use).

3 - Disclosure of the most influential variables on the use of Instagram program in light of its support for small projects for productive families.

4 - Detection of the most variables affecting the success of small projects for families producing the sample of the research.

The research reached:

1 - There are differences of statistical significance between the average scores of the sample in the role of the program Astscramm depending on the variables of the study.

2 - There are differences of statistical significance between the average scores of the sample in the management of small projects of productive families depending on the variables of the study.

3- There is a correlation between the questionnaire of the Instagram program and the questionnaire of the small projects of the productive families.

4 - There is a correlation between the questionnaire and the questionnaire of small projects for productive families and study variables.

5- The percentage of participation of the factors affecting the awareness of the role of the Instagram program.

6. The percentage of participation of factors affecting the management of small enterprises of productive households.

I recommend searching on:

1 - to work on the employment of modern communications technology (Alastscram) program because of the many positive effects especially in support of small private enterprises.

2 - Provide individuals with information that helps them to differentiate between different products through the use of the Alastscram program to display products of their small projects.

3 - Activating the role of individuals through the use of Instagram in solving the problems of unemployment by exploiting their energies and adjusting their behavior in order to achieve profitability for their small projects.

4 - Spread awareness of the importance of family cohesion and the importance of sitting and dialogue with the family and rationalize the use of the program Alastskram so as not to affect the communication with the family.
\end{abstract}




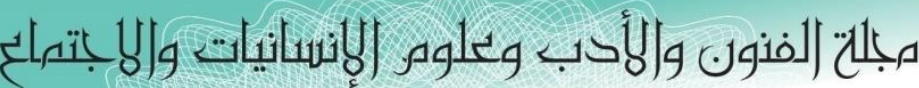

Journal of Arts, Literature, Humanities and Social Sciences

ISSN online: 2414 - 3383

ISSN print: 2616 - 3810

\section{العدد (42) أيلول - سبتهبر 2019}

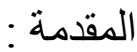

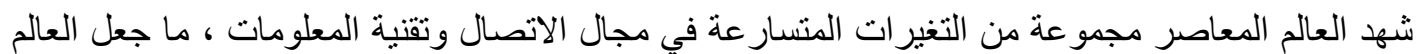

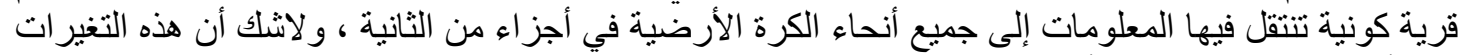

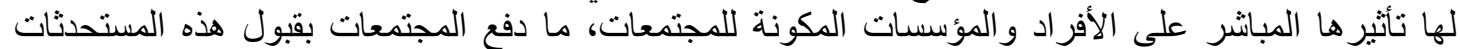

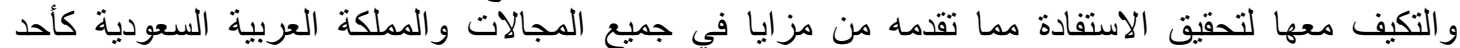

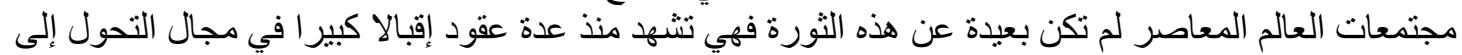

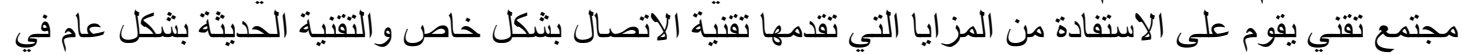

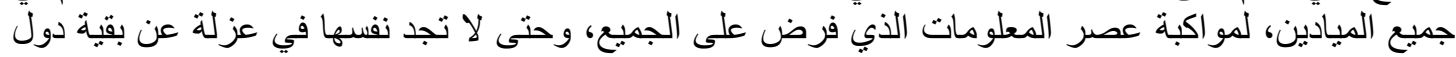

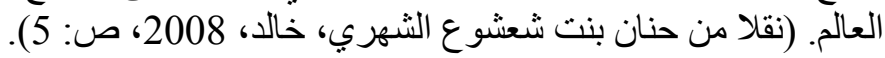

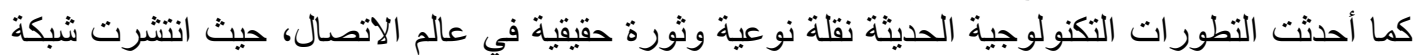

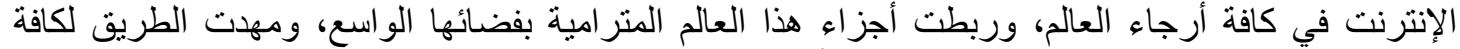

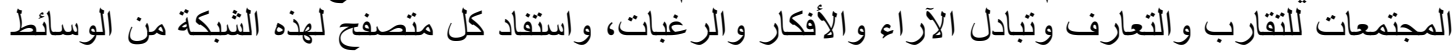

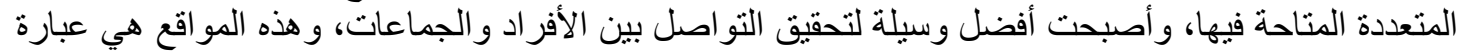

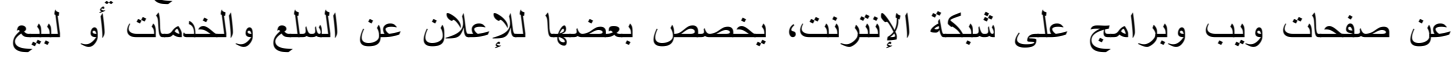
المنتجات. (محمد المنصور، 2012، صن: 24: 2012).

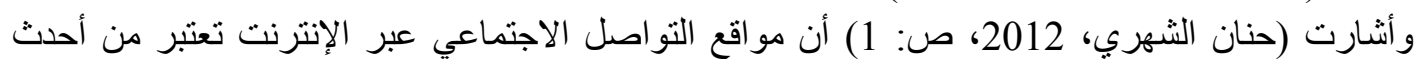

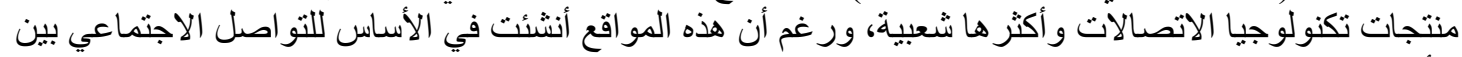

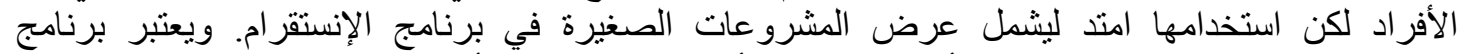

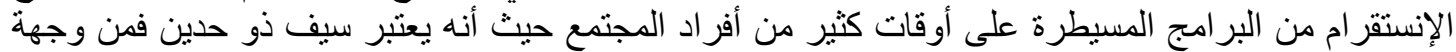

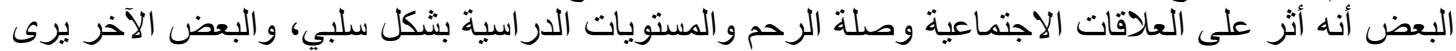

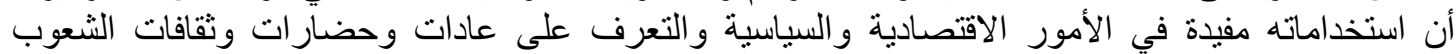

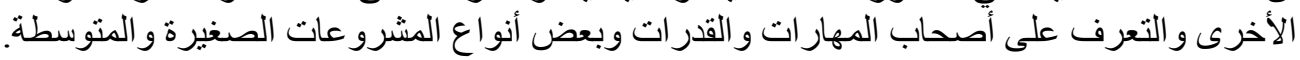

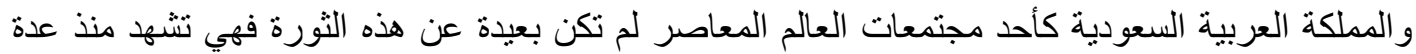

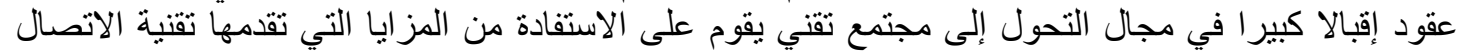

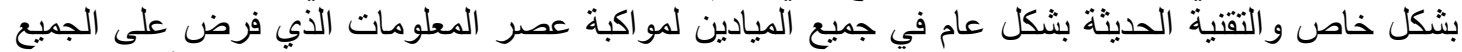

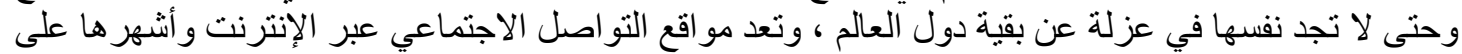

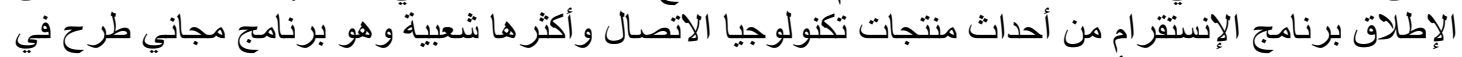

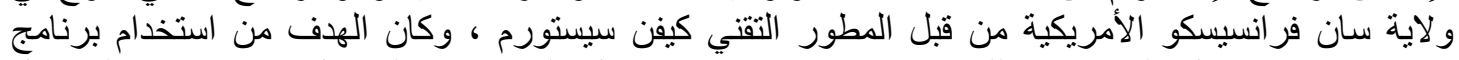

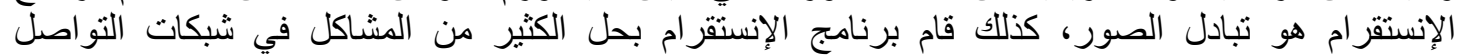

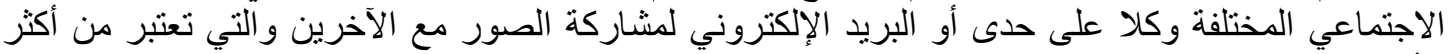

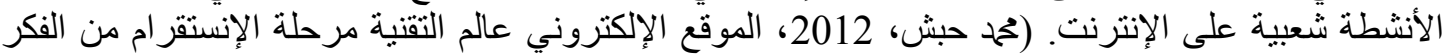

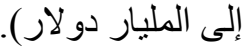

كما يرى كثير من الاقتصاديين أن تطوير المشروعات الصغيرة من أهم روافد عملية التتمية الاقتصادية

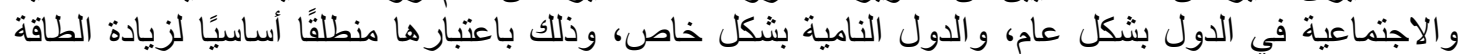

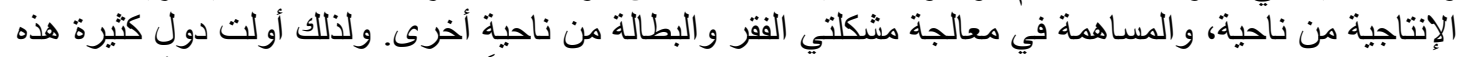

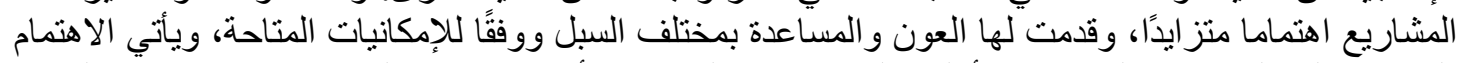

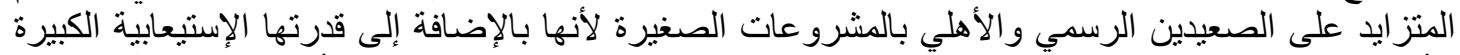

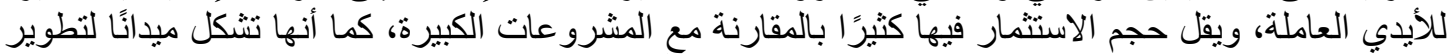

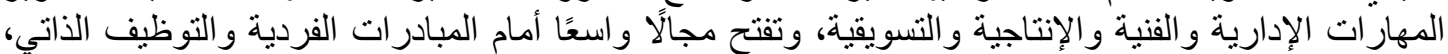
لما يخفف الضغط على القطاع العام من توفير فرص العمل. (د. ماهر حسن المحروق و د. د. مقابلة أيهاب، 2787

ص: 278-277). 


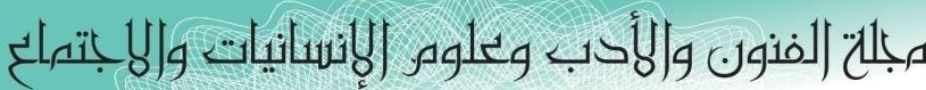

Journal of Arts, Literature, Humanities and Social Sciences

ISSN online: 2414 - 3383

ISSN print: 2616 - 3810

\section{العدد (42) أيلول - سبتهبر 2019}

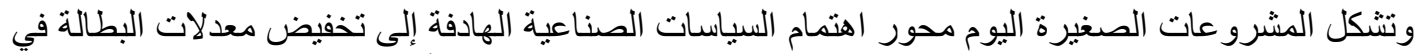

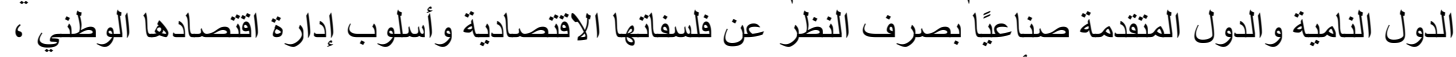

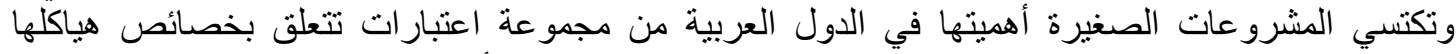

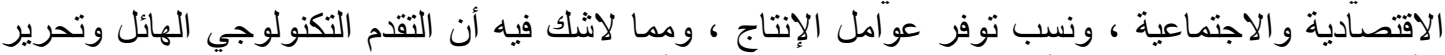

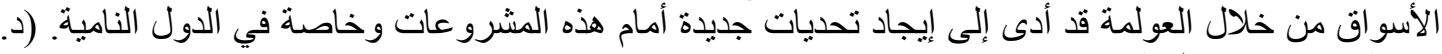
عبد العزيز بن عبداله الخضيري، 2006).

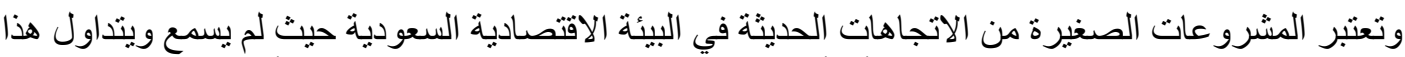

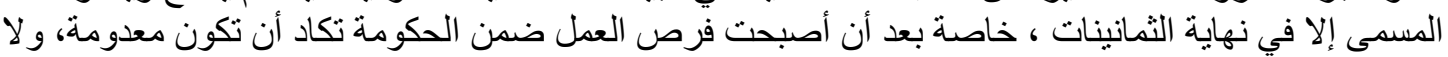

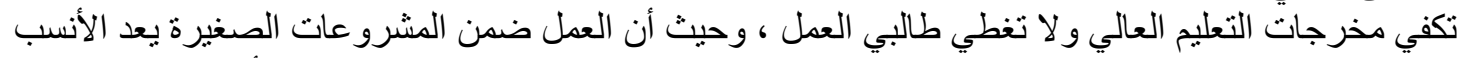

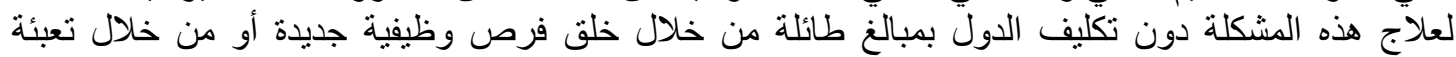

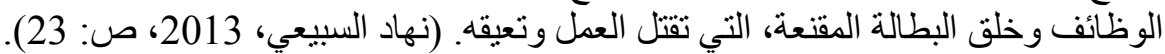

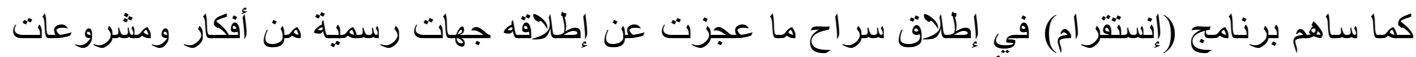

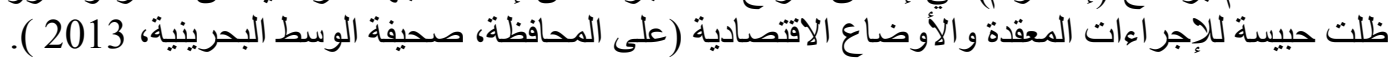

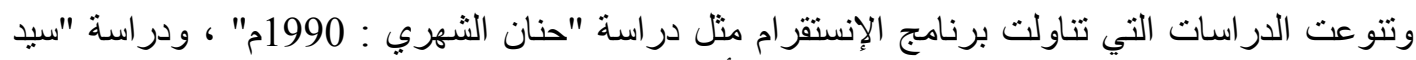

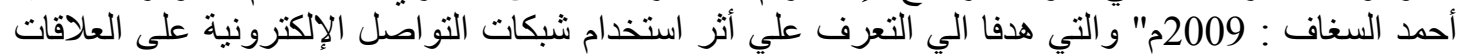

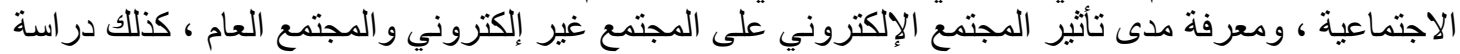

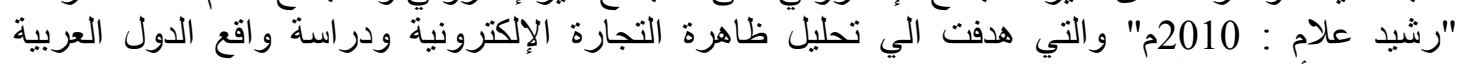
و الإسلامية أمام هذه الظاهرة .

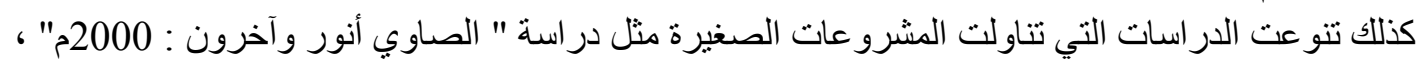

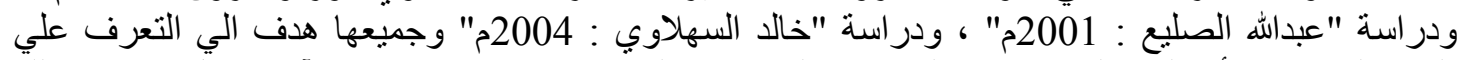

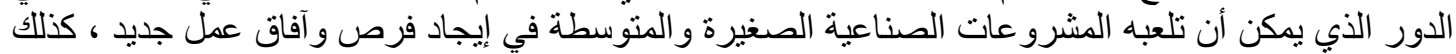

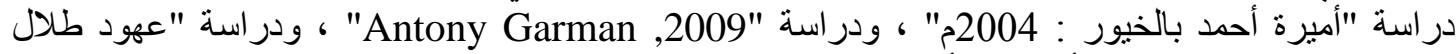

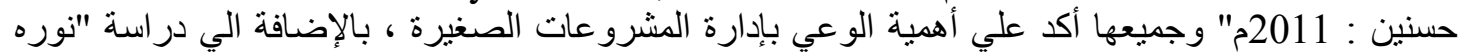
الزهر اني : 2013م" التي هدفت الي الكثف عن دور إدارة المشروعات الثنية الصغيرة في تحقيق التنمية الاقتصادية الإنة

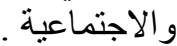

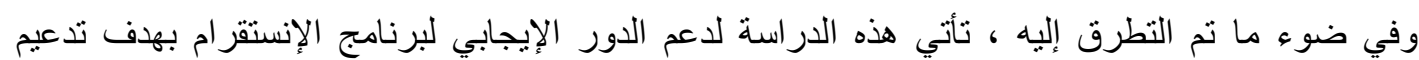

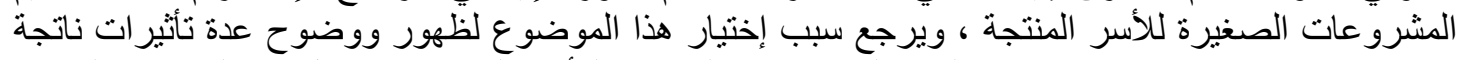

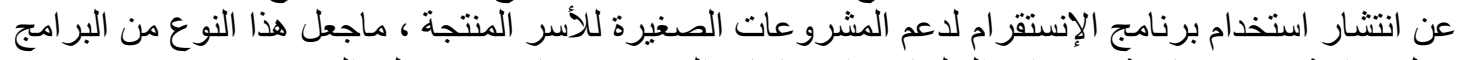

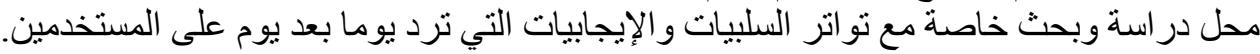

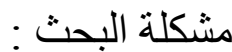

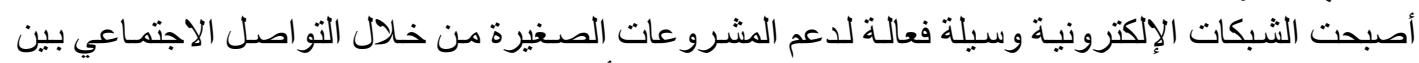

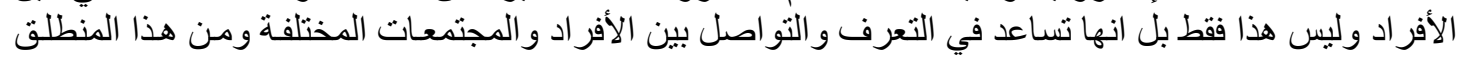

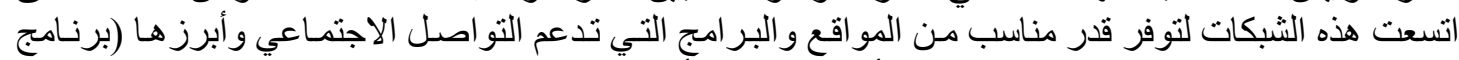

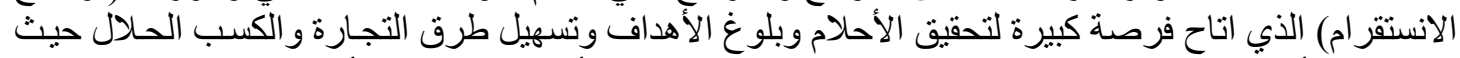

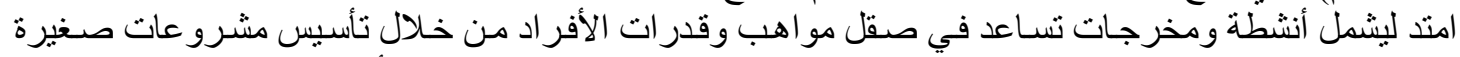

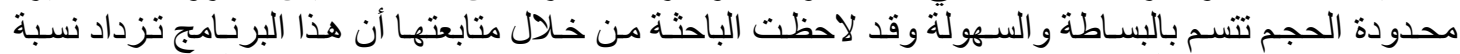

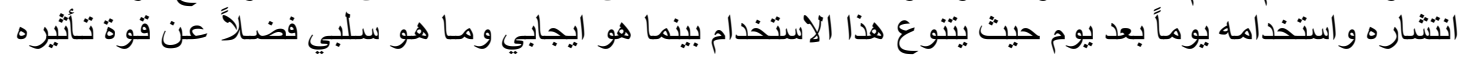

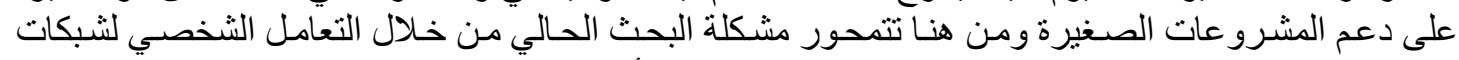

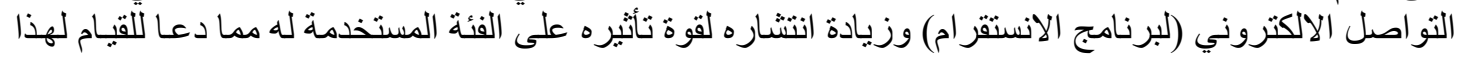
البحث لإلقاء الضوء على هذه الظاهرة من مجتمعنا. 


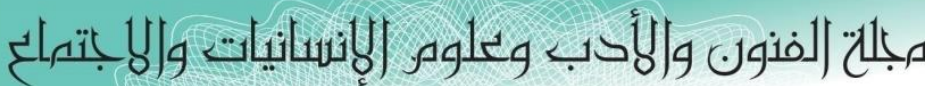

Journal of Arts, Literature, Humanities and Social Sciences

ISSN online: 2414 - 3383

ISSN print: 2616 - 3810

\section{العدد (42) أيلول - سبتمبر 2019}

على ضوء ما سبق صيغة مشكلة البحث في التساؤ لات التالية :

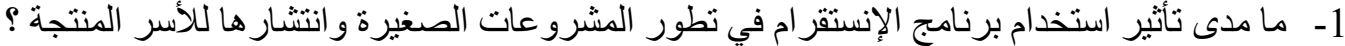

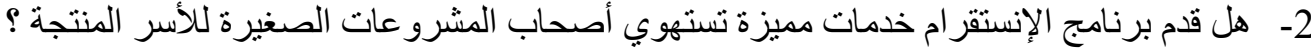

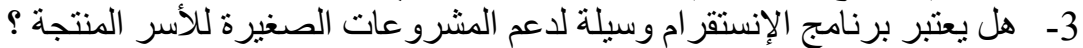

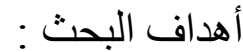

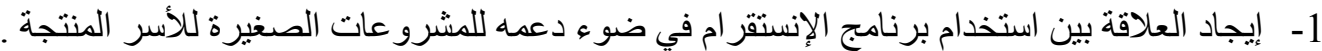

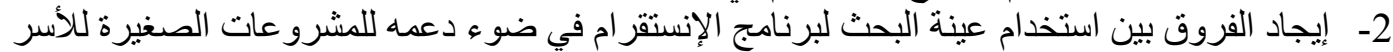

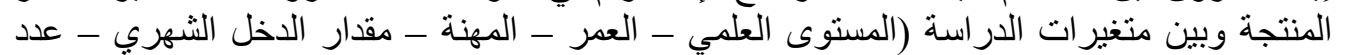

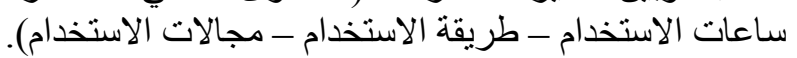

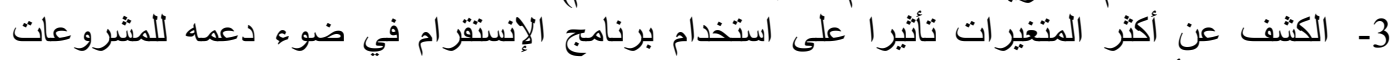

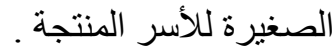

4- الكثف عن أكثر المتغير ات تأثيرًا على نجاح المشروعات الصغيرة للأسر المنتجة لعينة البحث.

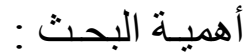

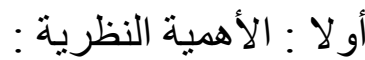

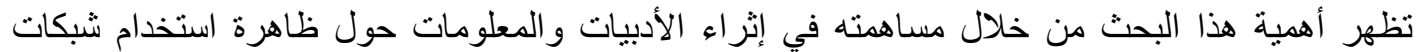

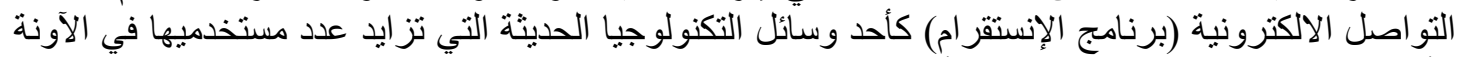

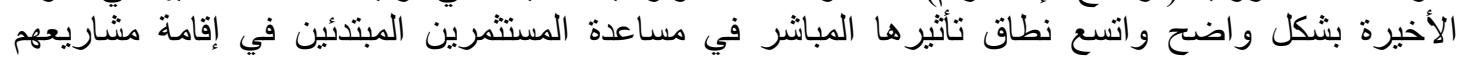

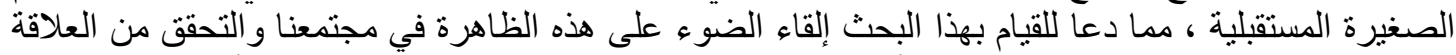

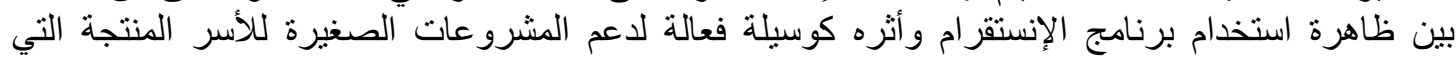

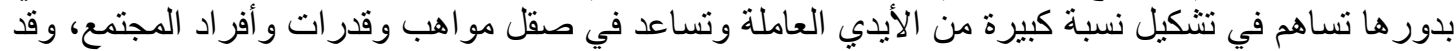

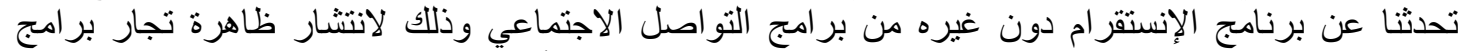

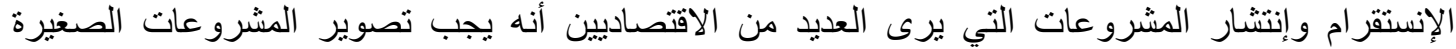
وتتجيع إقامتها وتطوير عملية التنمية الاقتصادية والاجتماعية في الدول المتقدمة بشكل عام والدول التانية النامية بشكل

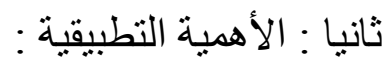

1- إلقاء الضوء على الضى الدور الريادي لبرنامج الإنستقر ام من قبل مستخدميه من خلال إتاحة المجال لحرية

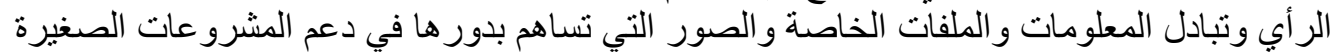

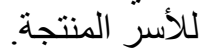

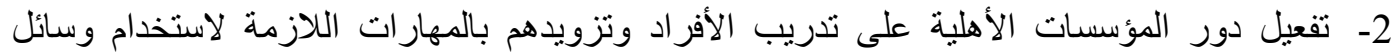

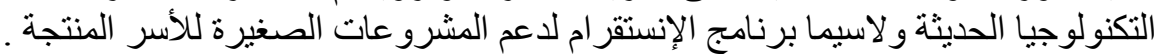

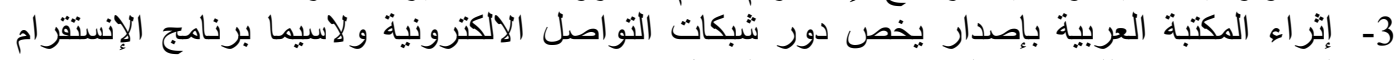
لتحقيق الاستفادة للباحثين و الدارسين في هذا لتران المجال.

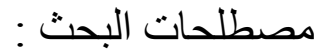

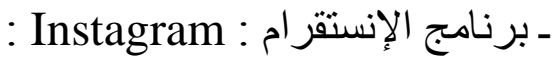

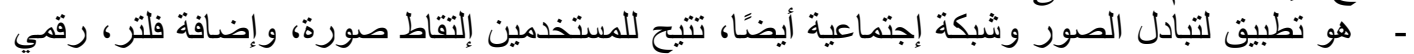

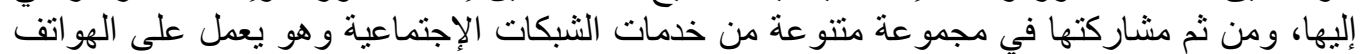

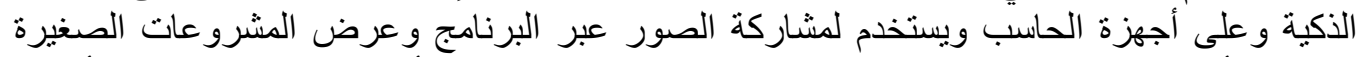

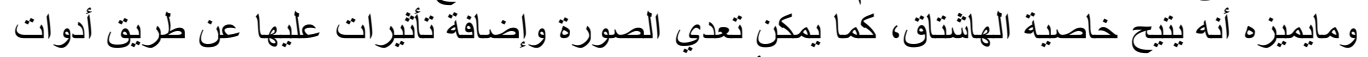

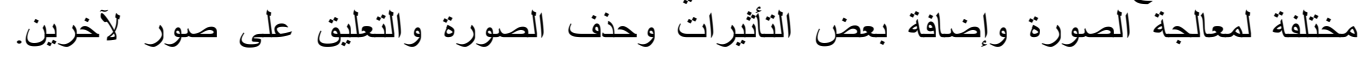

(http://ar.wikipedia.org/wiki) 


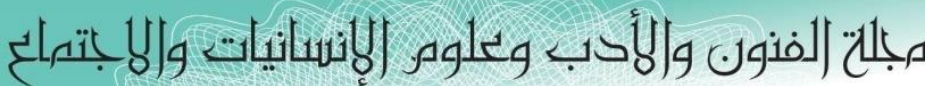

Journal of Arts, Literature, Humanities and Social Sciences

ISSN online: 2414 - 3383

ISSN print: 2616 - 3810

\section{العدد (42) أيلول - سبتمبر 2019}

ـ التعريف الإجر ائي لبرنامج الإنستقرام :

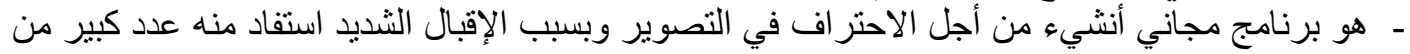

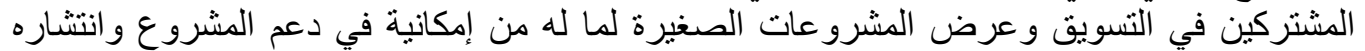
بسر عة فائقة ولما فيه من ربح اقتصادي هائل.

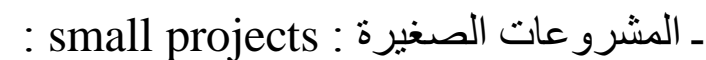
- مشروع لرفع مستوى الأسرة معيشيًا وتنمية قدرتها على العمل و الاستفادة من الطاقات المعطلة في الأسرة

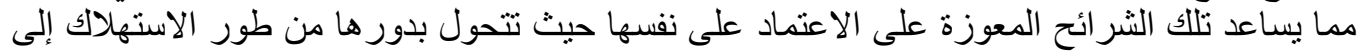

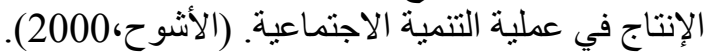
- هو المشروع الذي يمتلكه ويديره صاحبه بمفرده لكن حجم مبيعاته محدود داخل الصناعة التي يعمل بها. (عبد الحميد مصطفى أبو ناعم، 2002). ـ التعريف الإجر ائي للمشرو عات الصغيرة :

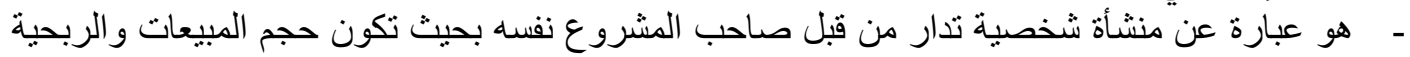
محدودة.

ـ Productive Families : الأسر المنتجة - مشروع يعمل علي تتمية القدرات البشرية المختلفة واستغلالها في تحويل خامات البيئة إلي أعمال

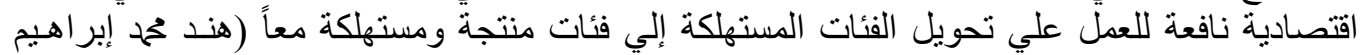

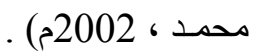
فروض البحث: 1- توجد فروق ذات دلالة إحصائية بين متوسط درجات أفراد العينة في دور برنامج الانستقر ام تبعا

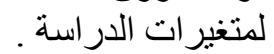
2- توجد فروق ذات دلالة إحصائية بين متوسط درجات أفراد العينة في إدارة المشروعات الصغيرة

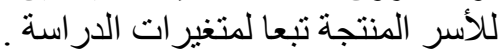

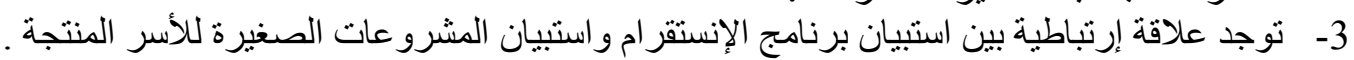

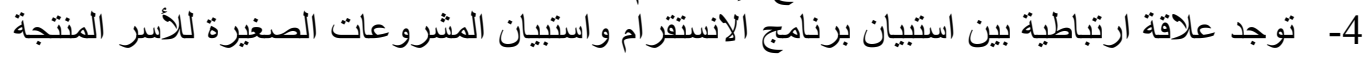

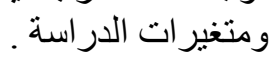

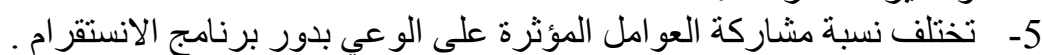

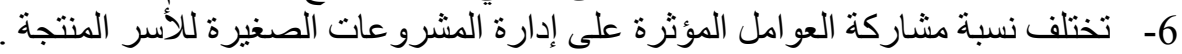

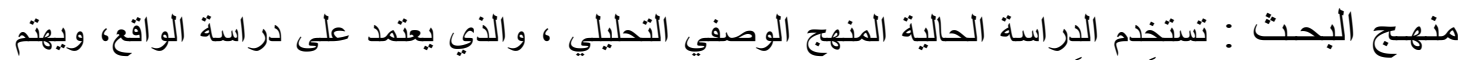

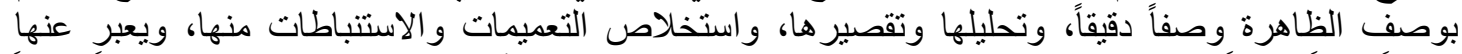

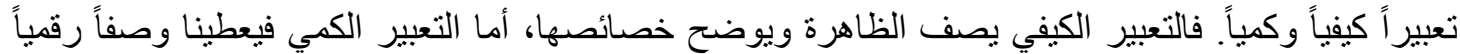

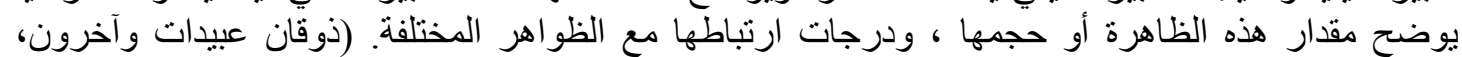

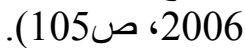
عينـة البحثث : عينة غير عشو ائية "قصدية" بلغ عددها (200) أسرة سعودية اللذين يقومون باستخدام برنامج الانستقر ام لدعم مشرو عاتهم الصغيرة عبر شبكة الإنة الإنترنت.

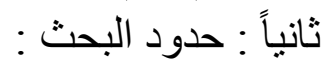
أـ الحدود المكانية : بناء على مشكلة الدراسة وأهدافها فقد طبقت الدراسة الميدانية على مجمو عة من الأسر

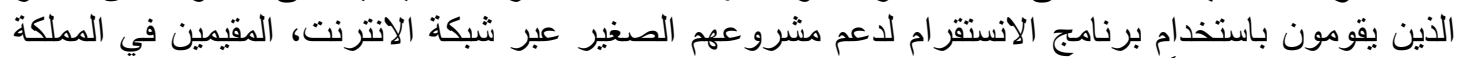
العربية السعودية نظرا لأن أداة البحث تم نشر ها عبر الثبكة العنكبوتية حيث يتعذر لنا تحديد منطقة معينة. 


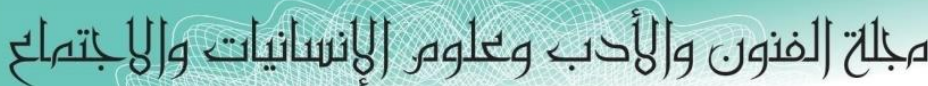

Journal of Arts, Literature, Humanities and Social Sciences

ISSN online: 2414 - 3383

ISSN print: 2616 - 3810

\section{العدد (42) أيلول -سبتمبر 2019}

بـ الحدود الزمانية : هي الفترة الني تم فيها توزيع الاستبيان الإلكتروني على أفراد العينة وهي الفترة من

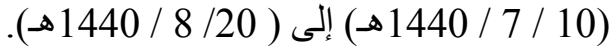

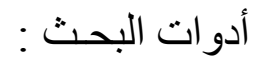

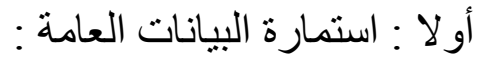

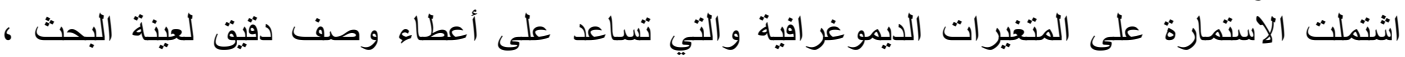

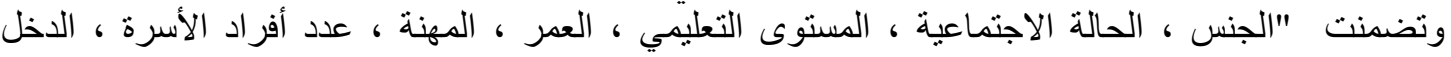

ثانيا : استبيان برنامج الانستقر ام :

الهدف منه معرفة دور برنامج الانستقر ام في دعم المشروعات الصغيرة وشمل العبارات من ( 1 ـ - 12 )

بو اقع 11 عبارة موجبة و 11 عبارة سالبة.

ثالثا : استبيان المشرو عات الصغيرة الصنارة للأسر المنتجة :

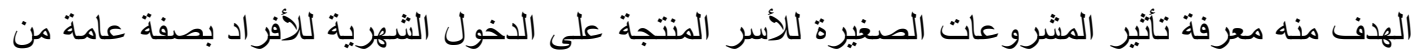

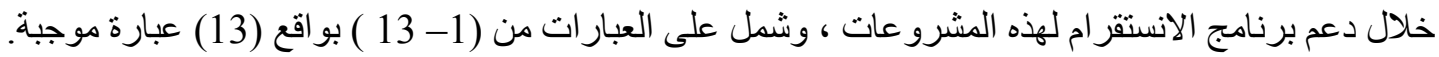

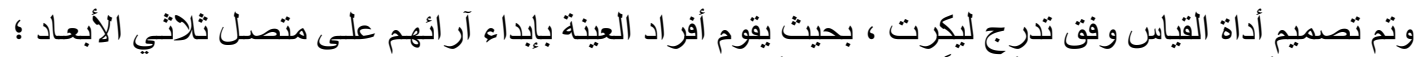

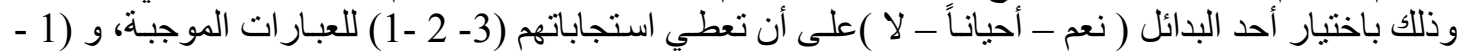

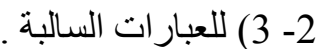

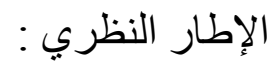

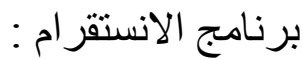

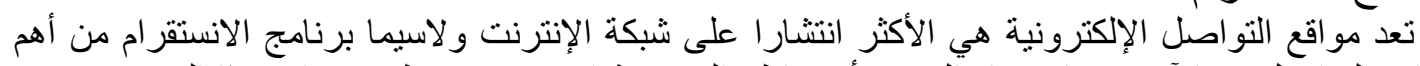

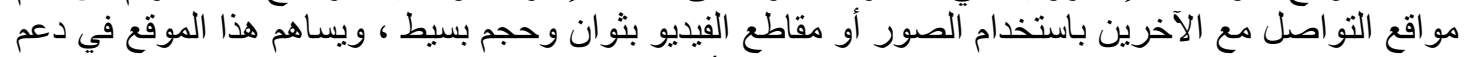

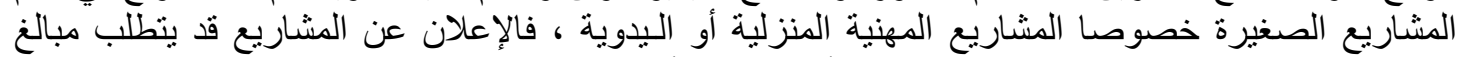

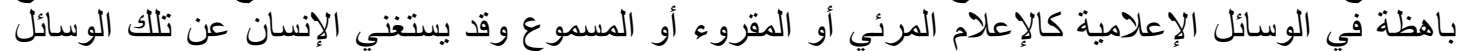

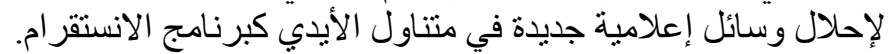

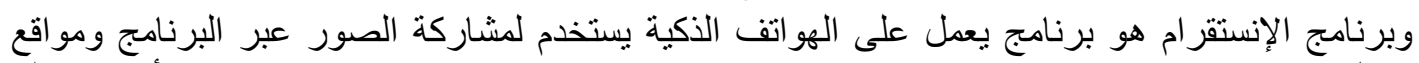

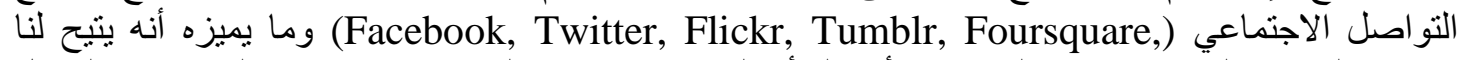

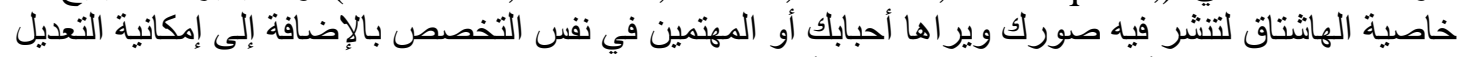

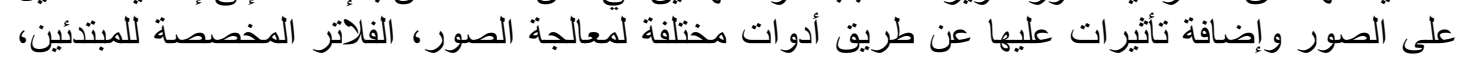

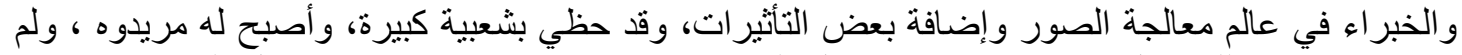

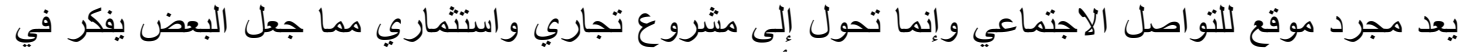

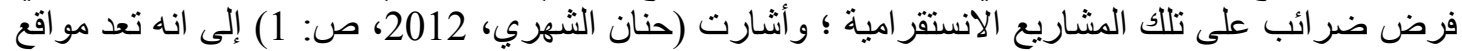

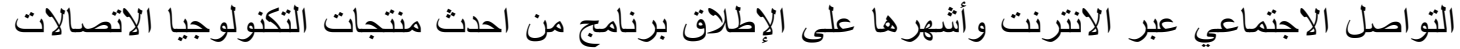

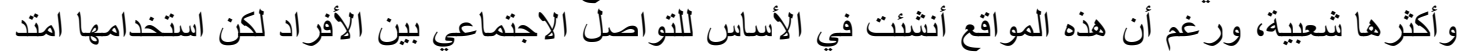

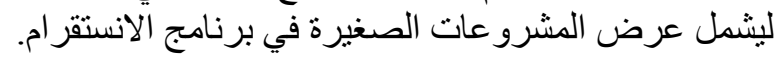
تعريف برنامج الانستقر ام :

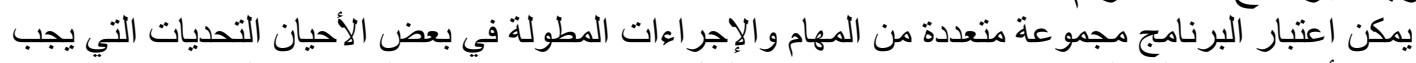

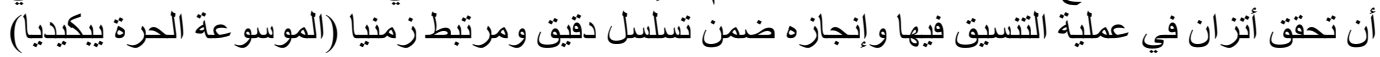

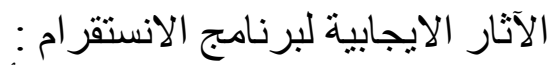

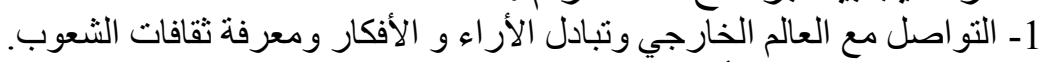
2- ممارسة العديد من الأنشطة التي تساعد على التقريب والته التواء اصل مع الآخرين. 


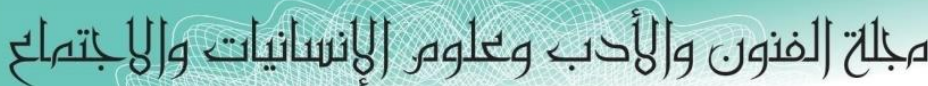

Journal of Arts, Literature, Humanities and Social Sciences

ISSN online: 2414 - 3383

ISSN print: 2616 - 3810

\section{العدد (42) أيلول - سبتهبر 2019}

3- تفتح أبو اب تمكن من إطلاق الإبداعات و المشاريع التي تحقق الأهداف. (http/wwww. dr-avsha. com)

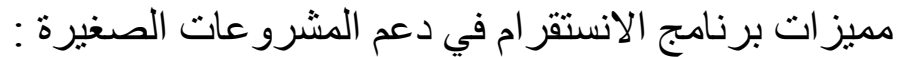

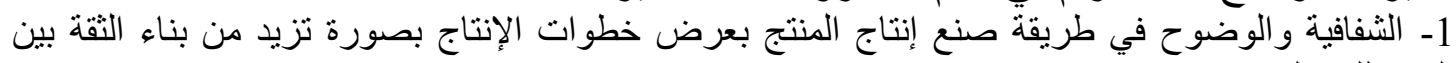
المستهرلك و المنتج. 2- توضيح القيم التي يسبر عليها صساحب المنتج.

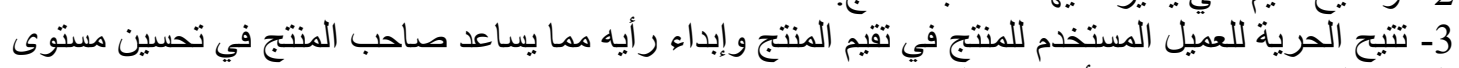
الخدمة المقدمة ويجذب عدد أكبر من العملاء التهاء 4- إمكانية التفاعل والمشّاركة لتطبيث الانستقرام مع مواقع التواصل اصل الاجتماعية الأخرى مما يزيد من نسبة المشاهدة و المشاركة 5- نطبيق الانستقر ام مبرمج للهو اتف الذكية مما يجعل التو اصل مع العملاء بشكل أسر ع وأسكل. (https: //theswaggerproj. com/using-instagam-small-/busiess)

المشرو عات الصغيرة : مات المشروع مجمو عة من المهام أو الأنشطة المترابطة بعضها البعض المحددة سلفا ذو مده تكلفه محدده، وله بداية ونهاية محدده. ويعرف (تحمد شعبان، 2012، صندة: 35) إدارة المشاريع فيقول هي عبارة عن جهد مؤقت ينم القيام به لإنشاء منتج أو خدمة أو نتيجة فردية.

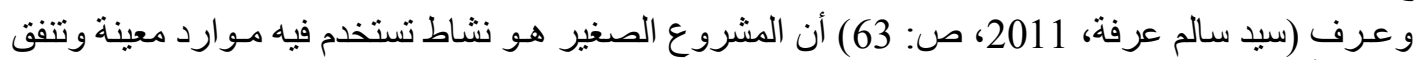
من اجل الأمو ال للحصول على منافع منوقعة من خلال فترة زمنية معينة.

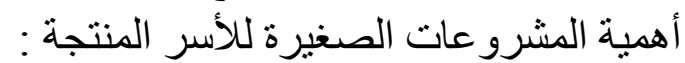

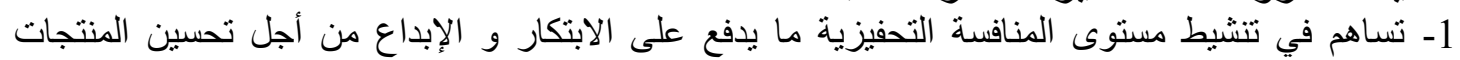
و الخدمات بماً يحقق الفعالية و الكفاءة منها.

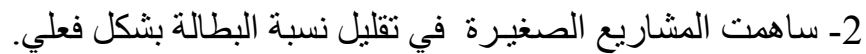

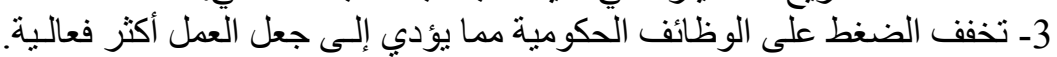

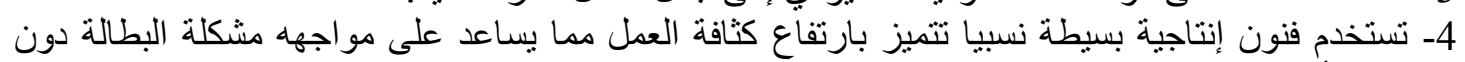
تكاليف رأسمالية عالية. 5- تقوم بتلبية احتياجات المجتمع من السلع والخدمات المتية المتخصصة التي ترتبط بأذواق وتفضيل المستهلكين

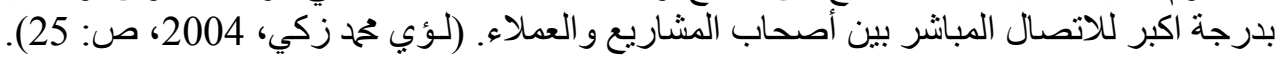

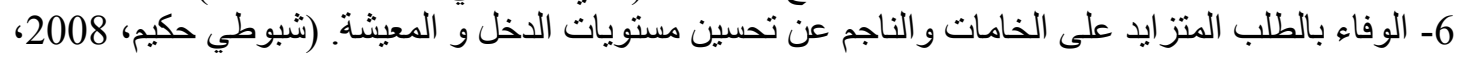

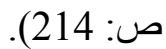

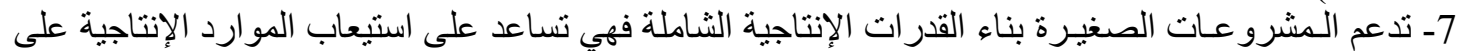

مستويات الاقتصاد كافة، وتساهم في إرساء أنظمة اقتصادية تتسم (صحيفة الوسيط البحرينية، 2009).

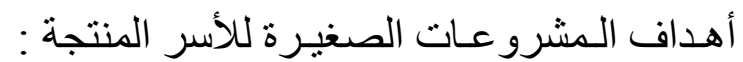

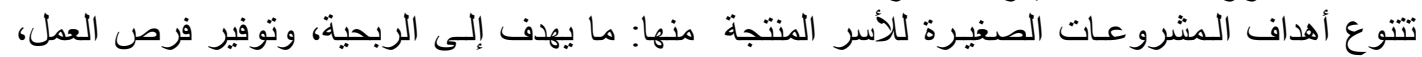

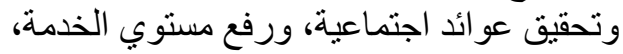
1- 2- ما يهدف إلى الربحية. 2- ما يهدف إلى توفير فرص الريحة العمل. 3- ما يهذف إلى تحقيق عو ائد اجتماعية. 4- ما يهدف إلى رفع مستوفي الخدمة.

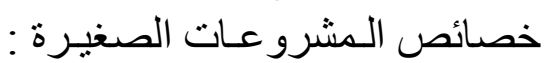

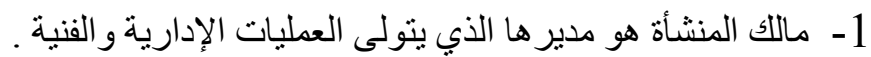

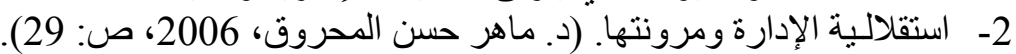




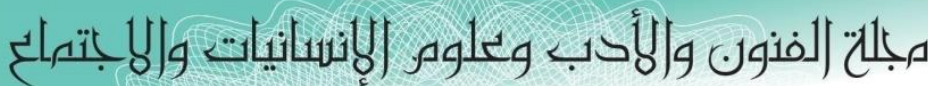

Journal of Arts, Literature, Humanities and Social Sciences

ISSN online: 2414 - 3383

ISSN print: 2616 - 3810

\section{العدد (42) أيلول - سبتهبر 2019}

$$
\begin{aligned}
& \text { 3- الارتقاء بمستويات الادخار و الاستثمار على اعتبار أنها مصدر ا جيدا للادخار ات الخاصة. }
\end{aligned}
$$

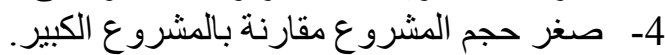

$$
\begin{aligned}
& \text { 5- ال الحتاج إلى تمويل كبير. }
\end{aligned}
$$

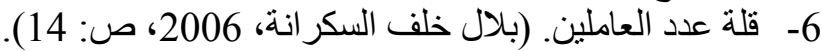

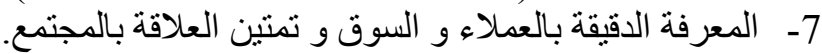

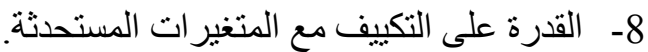

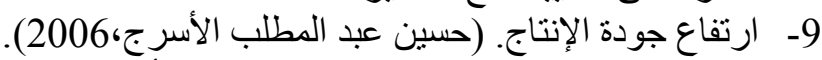

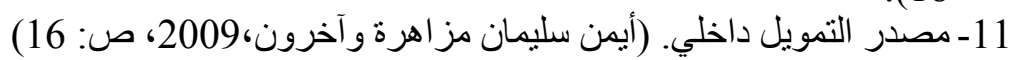

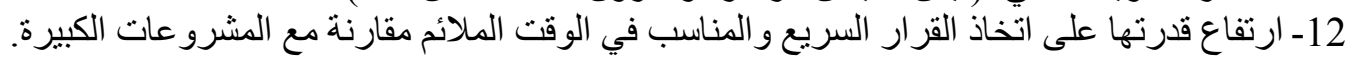

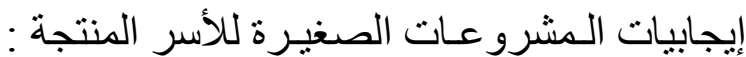

$$
\begin{aligned}
& \text { 1- إمكانبة تحقيق السرية في العمل. }
\end{aligned}
$$

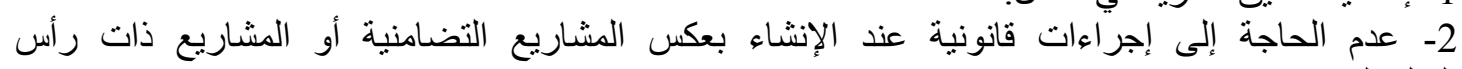

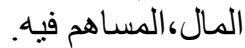
3- استقلال المالك بالثر ارات الت و إدارة المشروع. 4- 2- حصول الماللك على كامل الربح.

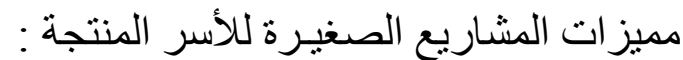

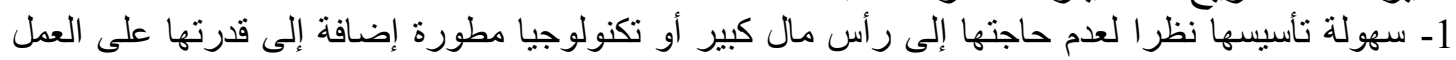

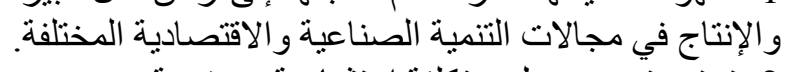

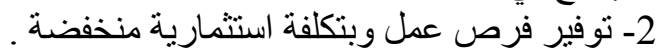

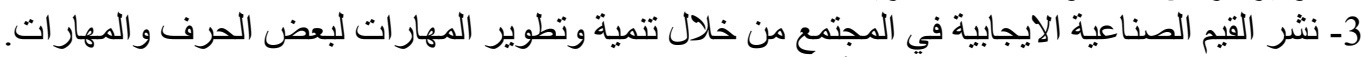

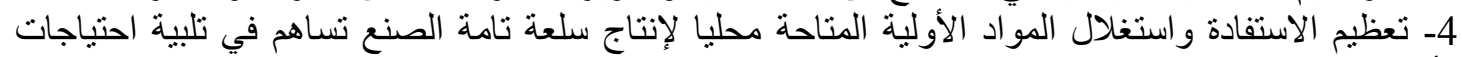

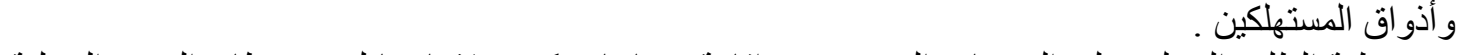
5- تغطية الطلب المحلي على المنتجات التي يصعب إقامة صناعات كبيرة لإنتاجها لضيق نطاق السوق المحلية

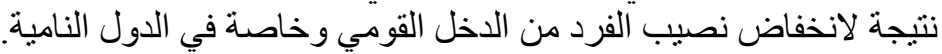

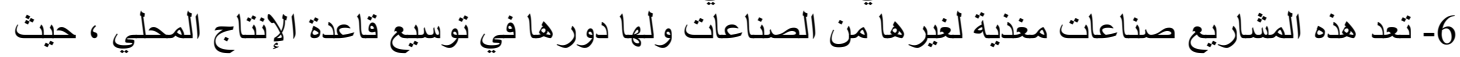

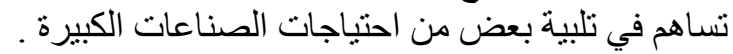

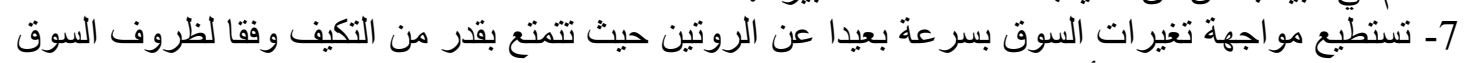

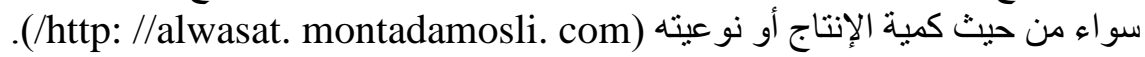

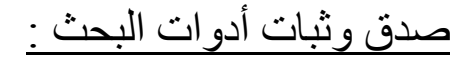

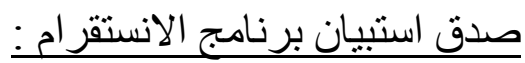

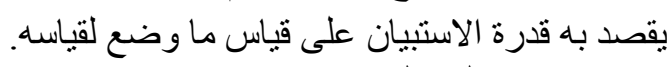

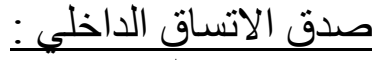

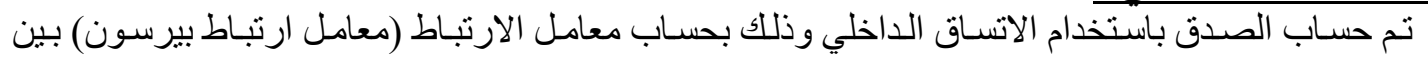

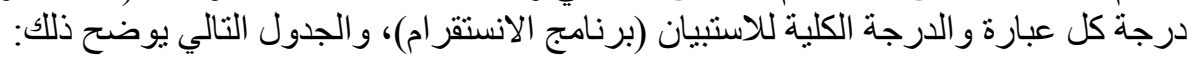




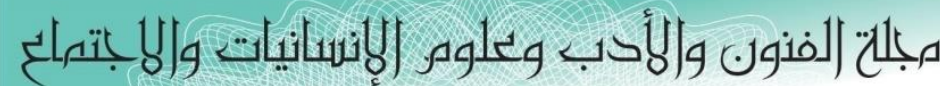

Journal of Arts, Literature, Humanities and Social Sciences

ISSN online: 2414 - 3383

ISSN print: 2616 - 3810

\section{العدد (42) أيلول - سبتمبر 2019}

جدول (1) قيم معاملات الارنباط بين درجة كل عبارة

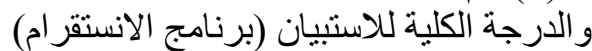

\begin{tabular}{|c|c|c|}
\hline الدلالة & الارتباط & م \\
\hline 0.05 & 0.615 & -1 \\
\hline 0.01 & 0.767 & -2 \\
\hline 0.01 & 0.946 & -3 \\
\hline 0.01 & 0.825 & -4 \\
\hline 0.01 & 0.884 & -5 \\
\hline 0.01 & 0.916 & -6 \\
\hline 0.05 & 0.639 & -7 \\
\hline 0.05 & 0.642 & -8 \\
\hline 0.01 & 0.708 & -9 \\
\hline 0.01 & 0.853 & -10 \\
\hline 0.01 & 0.735 & -11 \\
\hline 0.01 & 0.952 & -12 \\
\hline
\end{tabular}

يتضـح مـن الجدول أن معـاملات الارتبـاط كلهـا دالـة على مستوى ( 0.01 - 0.05 ) لاقتر ابها مـن الواحد الصحيح مما يدل على صدق وتجانس عبار ات الاستبيان.

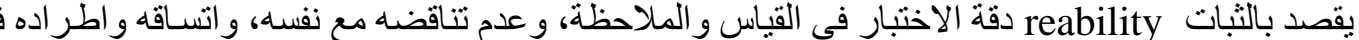

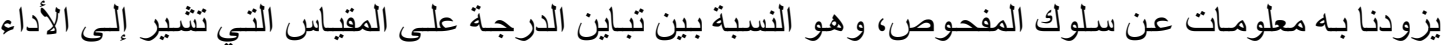

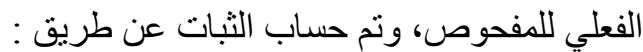
1 - معامل الفا كرونباخ Alpha Cronbach 2- طريقة التجزئة النصفية Split-half

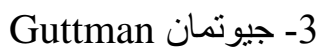

جدول (2) قيم معامل الثبات لاستبيان برنامج الانستقر ام

\begin{tabular}{|c|c|c|c|}
\hline جيوتمان & التجزئة النصفية & معامل الفا & المحور \\
\hline 0.891 & $0.963-0.852$ & 0.909 & ثبات استبيان برنامج الانستقر ام \\
\hline
\end{tabular}

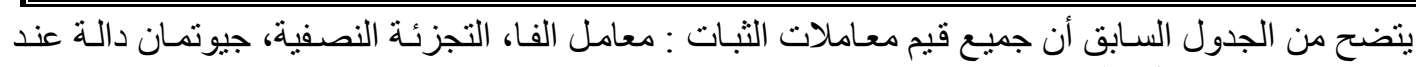

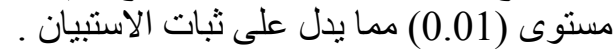

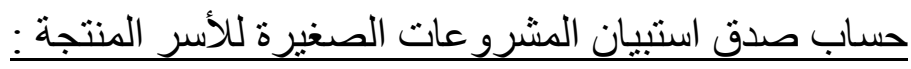

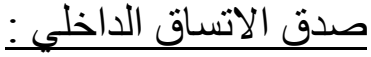

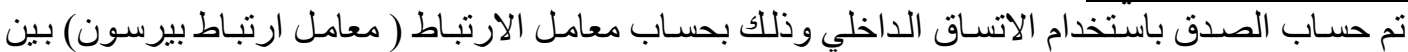

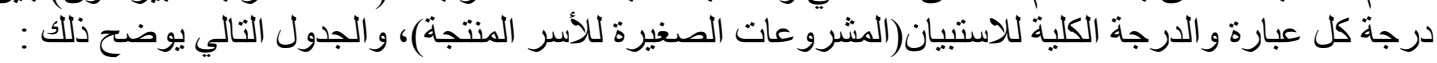




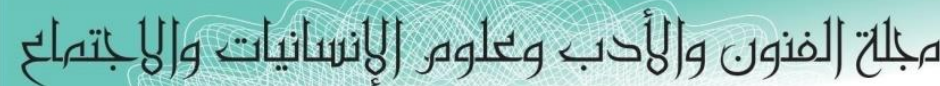
Journal of Arts, Literature, Humanities and Social Sciences

ISSN online: 2414 - 3383

ISSN print: 2616 - 3810

\section{العدد (42) أيلول - سبتهبر 2019}

جدول (3) قيم معاملات الارتباط بين درجة كل عبارة و الدرجة

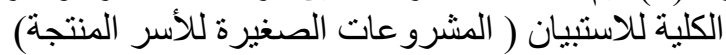

\begin{tabular}{|c|c|c|}
\hline الدلالة & الارتباط & 5 \\
\hline 0.01 & 0.791 & -1 \\
\hline 0.01 & 0.863 & -2 \\
\hline 0.01 & 0.775 & -3 \\
\hline 0.05 & 0.603 & -4 \\
\hline 0.01 & 0.899 & -5 \\
\hline 0.05 & 0.628 & -6 \\
\hline 0.01 & 0.924 & -7 \\
\hline 0.01 & 0.960 & -8 \\
\hline 0.01 & 0.713 & -9 \\
\hline 0.01 & 0.806 & -10 \\
\hline 0.05 & 0.611 & -11 \\
\hline 0.05 & 0.635 & -12 \\
\hline 0.01 & 0.745 & -13 \\
\hline
\end{tabular}

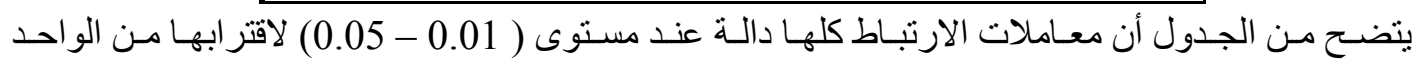
الصحيح مما يدل على صدق وتجانس عبار ات الاستبيان. الثبات

جدول (4) قيم معامل الثبات لاستبيان المشرو عات الصغيرة للأسر المنتجة

\begin{tabular}{|c|c|c|c|}
\hline جيو تمان & التجزئة النصفية & معامل الفا & 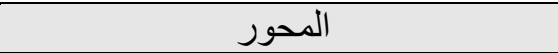 \\
\hline 0.824 & $0.894-0.786$ & 0.837 & ثبات المشروعات الصغيرة للأسر المنتجة \\
\hline
\end{tabular}

يتضح من الجدول السابق أن جميع قيم معاملات الثبات : معامـل الفـا، التجزئة النصفية ، جيوتمـان دالة عند مستوى (0.01) مما يدل على ثبات الاستبيان.

البيانات العامة

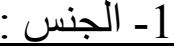

جدول (5) نوزيع أفر اد عينة البحث تبعاً لمتغير الجنس

\begin{tabular}{|c|c|c|}
\hline النسبةة\% & العدد & الجنس \\
\hline$\% 37$ & 74 & ذكر \\
\hline$\% 63$ & 126 & أنثى \\
\hline$\% 100$ & 200 & المجموع \\
\hline
\end{tabular}

يتضح من جدول (5) أن 126 من أفراد عينة البحث إناث بنسبة 63\% ، بينما 74 من أفراد عينة البحث

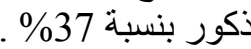




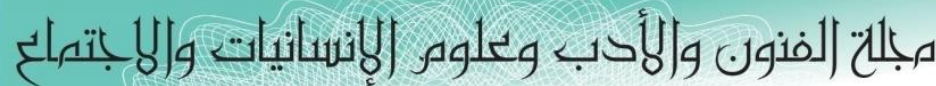

Journal of Arts, Literature, Humanities and Social Sciences

ISSN online: 2414 - 3383

ISSN print: 2616 - 3810

\section{العدد (42) أيلول - سبتمبر 2019}

2- 20 - 2 الحالة الاجتماعية :

جدول (6) توزيع عينة البحث تبعاً لمتغير الحالة الاجتماعية

\begin{tabular}{|c|c|c|}
\hline النسبة\%\% & 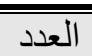 & الحالة الاجتماعية \\
\hline$\% 46$ & 92 & متزوج \\
\hline$\% 54$ & 108 & غير متزوج \\
\hline$\% 100$ & 200 & المجموع \\
\hline
\end{tabular}

يتضح من جدول (6) أن 108 من أفراد عينة غير متزوجين بنسبة 54\% ، بينما 92 من أفراد عينة البحث

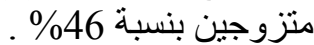

3- المستوى التعليمي :

جدول (7) توزيع أفر اد عينة البحث تبعاً لمتغير المستوى التعليمي

\begin{tabular}{|c|c|c|}
\hline النسبة\%\% & العدد & المستوى التعليمي \\
\hline$\% 19$ & 38 & الشهادة الثانوية فأقلّل \\
\hline$\% 30.5$ & 61 & دبلوم \\
\hline$\% 41$ & 82 & الثهادة الجامعية \\
\hline$\% 9.5$ & 19 & ماجستير ، دكتور اه \\
\hline$\% 100$ & 200 & المجموع \\
\hline
\end{tabular}

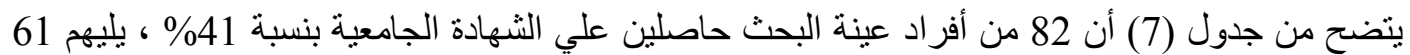

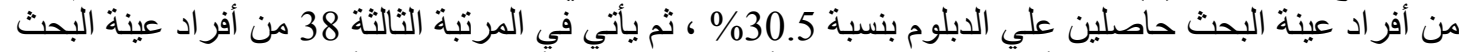

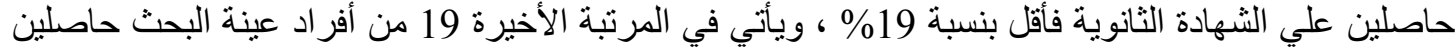

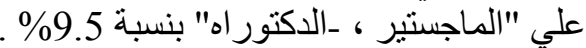

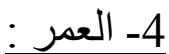

جدول (8) توزيع أفر اد عينة البحث تبعاً لمتغير العمر

\begin{tabular}{|c|c|c|}
\hline النسبة\%\% & العدد العد & العمر \\
\hline$\% 23.5$ & 47 & أقل من 25 سنة \\
\hline$\% 40.5$ & 81 & من 25 سنة لأقل من 30 سنة \\
\hline$\% 36$ & 72 & من 30 سنة فأكثر \\
\hline$\% 100$ & 200 & المجموع \\
\hline
\end{tabular}

يتضح من جدول (8) أن 81 من أفراد عبنة البحث تراوحت أعمار هم من 25 سنة لأقل من 30 سنة بنسبة

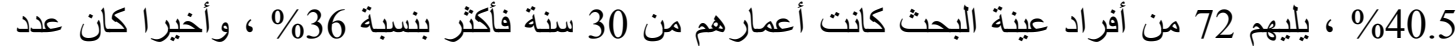

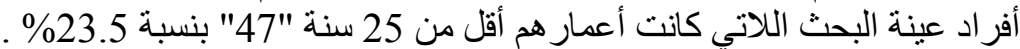


مبلحة لفنون والأدب وعلوه الإنسانيات و|لبابتهاع

Journal of Arts, Literature, Humanities and Social Sciences

ISSN online: 2414 - 3383

ISSN print: 2616 - 3810

\section{العدد (42) أيلول - سبتمبر 2019}

جدول (9) توزيع أفر اد عينة البحث تبعاً لمتغير المهنة

\begin{tabular}{|c|c|c|}
\hline النسبة\%\% & العدد - ل العد & المهنة \\
\hline$\overline{0 \% 35.5}$ & $\overline{71}$ & وظيفة حكومية \\
\hline$\% 19$ & 38 & قطاع خاص \\
\hline$\% 13.5$ & 27 & أعمال حرة \\
\hline$\% 32$ & 64 & طالب / لا يعمل \\
\hline \%100 & $\overline{200}$ & المجموع \\
\hline
\end{tabular}

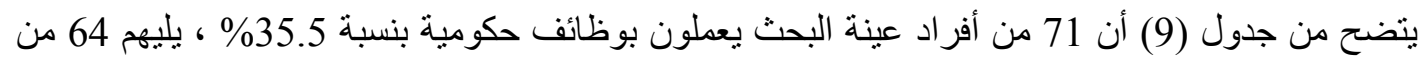

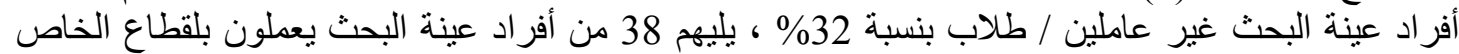

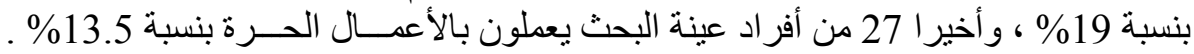
6- عدد أفر اد الأسرة : عأسرة

جدول (10) توزيع أسر عينة البحث تبعاً لعدد أفر ادها

\begin{tabular}{|c|c|c|}
\hline النسبة0\% & العدد ال العد & عدد أفر اد الأسرة \\
\hline$\% 33$ & 66 & أقل من 5 أفر اد \\
\hline$\% 41.5$ & 83 & من 5 أفر اد إلى 7 أفر اد \\
\hline$\% 25.5$ & 51 & من 8 أفر اد فأكثر \\
\hline$\% 100$ & 200 & المجموع \\
\hline
\end{tabular}

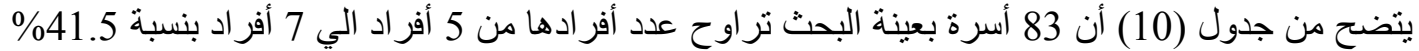

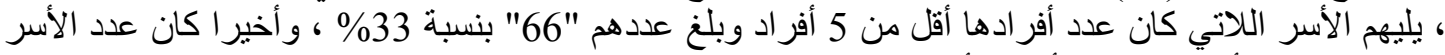

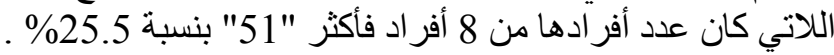

جدول (11) نوزيع أسر عينة البحث وفقاً لفئات الدخل المختلفة

\begin{tabular}{|c|c|c|}
\hline النسبة\%\% & 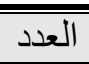 & الاخل الشهري للأسرة \\
\hline$\% 13.5$ & 27 & أقل من 3000 ربال \\
\hline$\% 22$ & 44 & من 3000 ربال إلى أقل من 8000 ربال \\
\hline$\% 35$ & 70 & من 8000 ربال إلى أقل من 13000 ربال \\
\hline$\% 29.5$ & 59 & من 13000 ربال فأكثر \\
\hline$\%$ \%100 & 200 & المجموع \\
\hline
\end{tabular}

يتضح من جدول (11) أن أكبر فئات الدخل الشهري لأسر عينة البحث كان في الفئة (من 8000 ربال إلى الفى

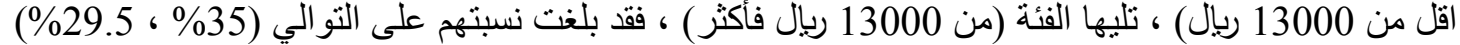

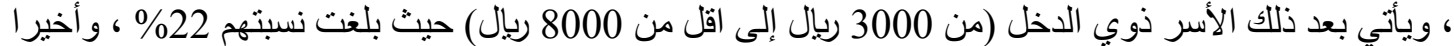

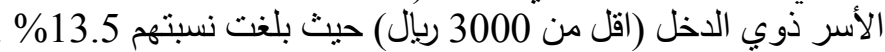




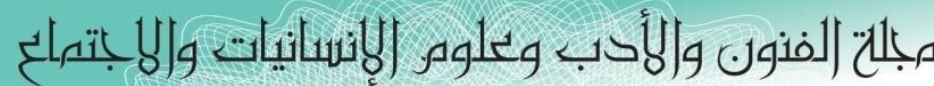
Journal of Arts, Literature, Humanities and Social Sciences

ISSN online: 2414 - 3383

ISSN print: 2616 - 3810

\section{العدد (42) أيلول - سبتهبر 2019}

8- عدد ساعات الاستخدام اليومي لبرنامج الانستقر ام :

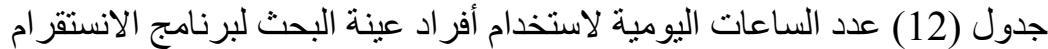

\begin{tabular}{|c|c|c|}
\hline النسبة\%\% & 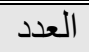 & عدد ساعات الاستخدام اليومي لبرنامج الانستقر ام \\
\hline$\% 15$ & 30 & لا يستخدم بشكل يومي \\
\hline$\% 23$ & 46 & أقل من ساعتين \\
\hline$\% 34$ & 68 & من ساعتين لأقلَ من 5 ساعات \\
\hline$\% 18.5$ & 37 & من 5 ساعات لأقل من 7 ساعات \\
\hline$\% 9.5$ & 19 & من 7 ساعات فأكثر \\
\hline$\% 100$ & 200 & المجموع \\
\hline
\end{tabular}

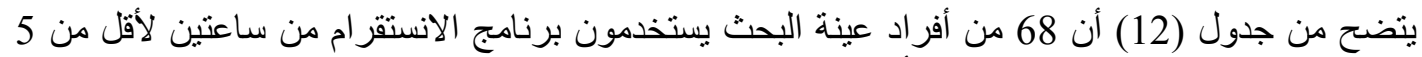

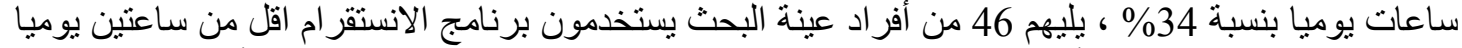

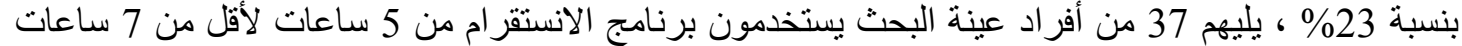

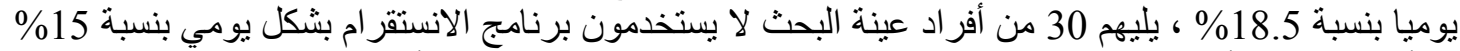

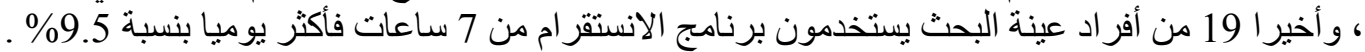

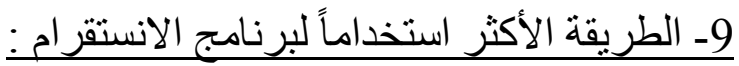

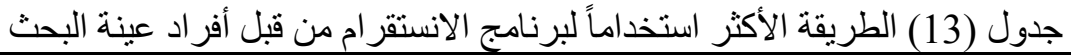

\begin{tabular}{|c|c|c|}
\hline النسبةة\% & العدد - العد & الطريقة الأكثر استخداماً لبرنامج الانستقر ام \\
\hline$\% 64.5$ & 129 & من الهاتف الجو ال \\
\hline$\% 35.5$ & 71 & الأجهزة اللوحية الالكترونية \\
\hline$\% 100$ & 200 & المجموع \\
\hline
\end{tabular}

يتضح من جدول (13) أن 129 من أفر اد عينة البحث يستخدمون برنامح الانستقر ام من الهاتف الجوال بنسبة الإنة 64.5\% ، بينما 71 من أفر اد عينة البحث يستخدمون برنامح الانستقرام من الأجهزة اللوحية الالكترونية بنسبة الأبة

10- مجالات استخدام برنامج الانستقر ام :

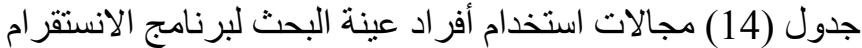

\begin{tabular}{|c|c|c|}
\hline النسبة\%\% & 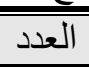 & مجالات استخدام برنامج الانستقر ام \\
\hline \%11.8 & 63 & لتبادل الأفكار وحرية التعبير عن الر أي \\
\hline$\% 21$ & 112 & متابعة الإعلانات \\
\hline$\% 22.3$ & 119 & وسيلة للتسوق و الثر اء \\
\hline$\% 9.6$ & 51 & وسيلة لنشر المشرو عات الصغيرة على نطاق و اسع \\
\hline$\% 12.6$ & 67 & وسيلة للتو اصل الاجتماعي \\
\hline$\% 15.4$ & 82 & وسيلة للتو اصل الثقافي \\
\hline$\% 7.3$ & 39 & وسيلة للتو اصل الديني \\
\hline$\% 100$ & 533 & المجموع \\
\hline
\end{tabular}

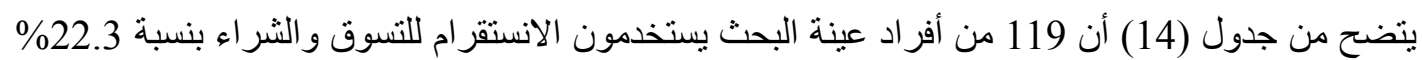

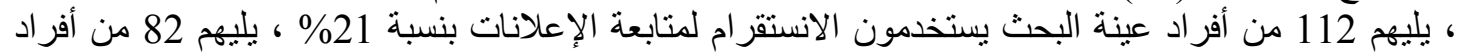
عينة البحث يستخدمون الانستقرام وسيلة للتواصل الثقافي بنسبة 15.4\% ، يليهم 67 من أفراد عينة البحث 


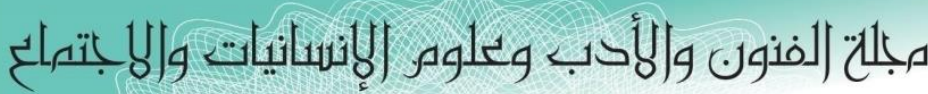
Journal of Arts, Literature, Humanities and Social Sciences

ISSN online: 2414 - 3383

ISSN print: 2616 - 3810

\section{العدد (42) أيلول - سبتمبر 2019}

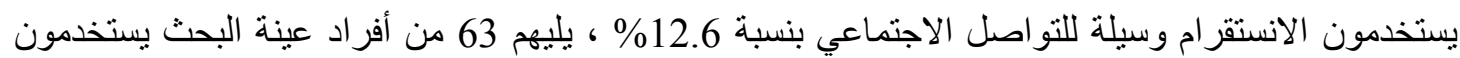

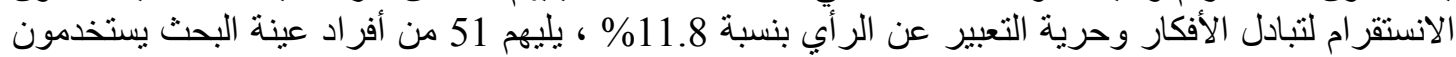

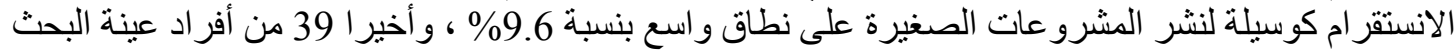

يستخدمون الانستقر ام وسيلة للتو اصل الديني بنسبة

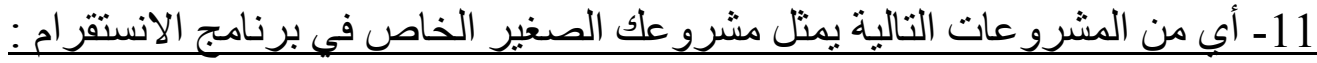
جدول (15) المشروع الصغير الخاص بأفر اد عينة البحث في برنامج الانستقر ام

\begin{tabular}{|c|c|c|}
\hline 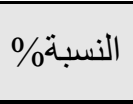 & العدد & أي من المشرو عات التالية يمثل مشرو علك الصغير الخاص في \\
\hline$\% 11.3$ & 73 & تنفيذ القطع المختلفة من الاكسسو ارات \\
\hline$\% 12.7$ & 82 & تتفيذ وتجميل ملابس الأطفال \\
\hline$\% 9.4$ & 61 & طباعة على التيشيرنات \\
\hline$\% 8.5$ & 55 & تزيين وتجميل الحقائب و الأحذية \\
\hline$\% 10.7$ & 69 & بيع المنتجات الجاهزة \\
\hline$\% 10.4$ & 67 & تنفيذ وتجميل قطع الأثاث و المفروشات ومكملات الزينة \\
\hline$\% 6.8$ & 44 & تجهيز وتنسيق الحفلات \\
\hline$\% 5.9$ & 38 & تحضير وتنفيذ وجبات غذائية خفيفة للمناسبات \\
\hline$\% 4.3$ & 28 & تنفيذ هدايا للمناسبات الخاصة " مو اليد، زواج " \\
\hline$\% 2.8$ & 18 & رسم وتصوير \\
\hline$\% 1.9$ & 12 & تصميم ديكور ات منزلية \\
\hline$\% 4.6$ & 30 & عمل خلطات للعناية بالجسم و البشرة \\
\hline$\% 6.9$ & 45 & تنفيذ قطع مختلفة من الكروشيه \\
\hline$\% 1.4$ & 9 & تزيين وتشريع السيارات \\
\hline$\% 2.3$ & 15 & تنفيذ قطع مختلفة من إكسسور ات السبار ات \\
\hline$\% 100$ & 646 & المجموع \\
\hline
\end{tabular}

يتضح من جدول (15) أن 82 من أفراد عينة البحث كان مشروعهم الصغير في برنامج الانستقرام تنفيذ

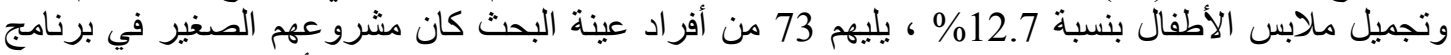

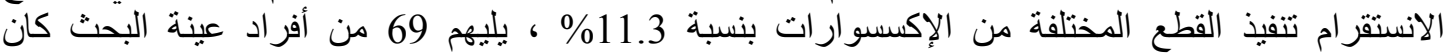

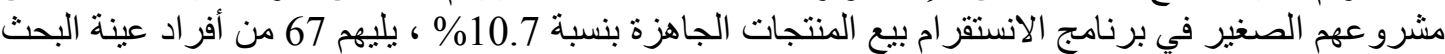

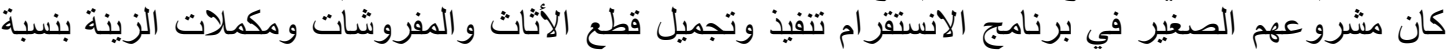

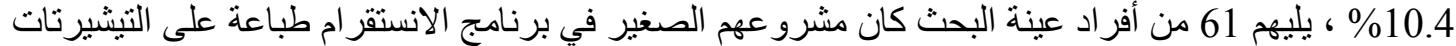

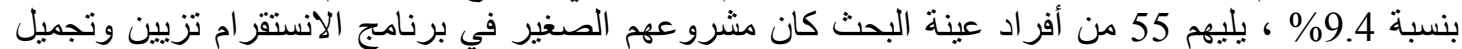

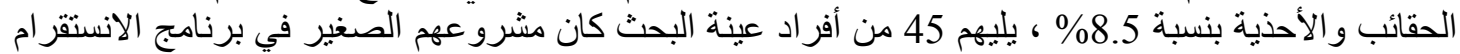

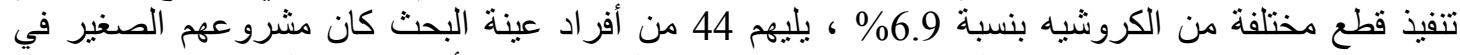

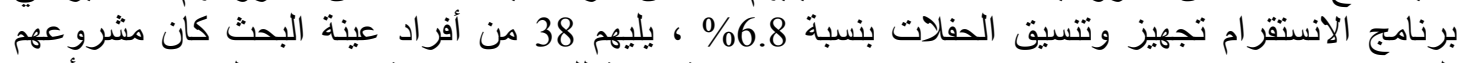

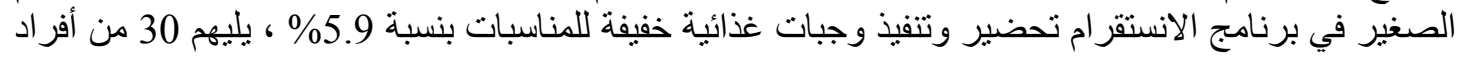

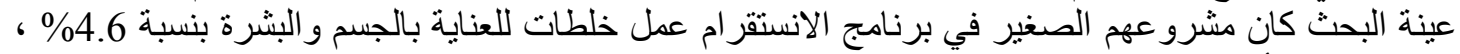

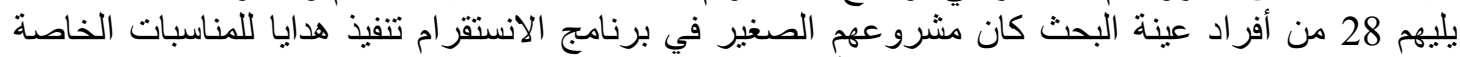

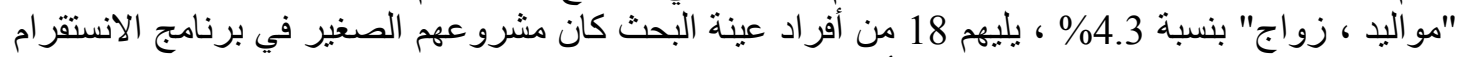

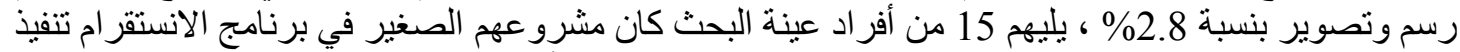
قطع مختلفة من إكسسوار ات السيار ات بنسبة 2.3\% ، يليهم 12 من أفراد عينة البحث كان مشرو عهم الصغير الانير 
مبلحة لفنون والأدب وعلوه الإنسانيات و|لبابتهاع Journal of Arts, Literature, Humanities and Social Sciences

ISSN online: 2414 - 3383

ISSN print: 2616 - 3810

\section{العدد (42) أيلول - سبتمبر 2019}

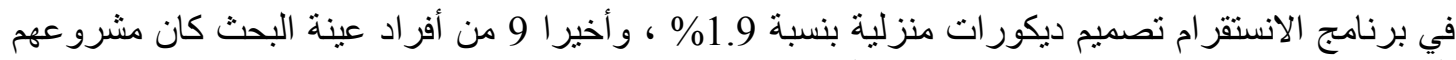

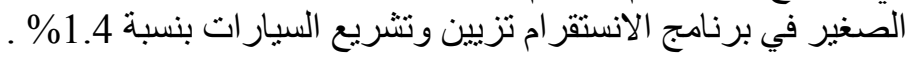

12- حسابك الشخصي في الانستقر ام :

جدول (16) الحساب الثخصي في الانستقر ام

\begin{tabular}{|c|c|c|}
\hline النسبة\%\% & العدد & حسابك الثخصي في الانستقر ام \\
\hline$\% 61$ & 122 & مفتوح " عام " \\
\hline$\% 39$ & 78 & مغلق " خاص " \\
\hline$\% 100$ & 200 & المجموع \\
\hline
\end{tabular}

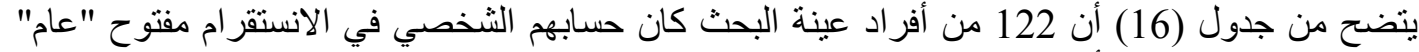

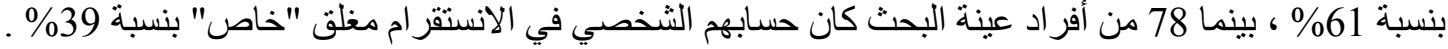

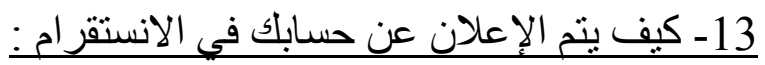

جدول (17) إعلان عينة البحث عن حسابهر في الانستقر ام

\begin{tabular}{|c|c|c|}
\hline النسبةة\%\% & العدد & كيف يتم الإعلان عن حسابك في الانستقر ام \\
\hline$\% 40$ & 80 & حساب مشترك آخر \\
\hline$\% 32.5$ & 65 & هاشتاق \\
\hline$\% 27.5$ & 55 & برنامج الواتس اب \\
\hline$\% 100$ & 200 & المجموع \\
\hline
\end{tabular}

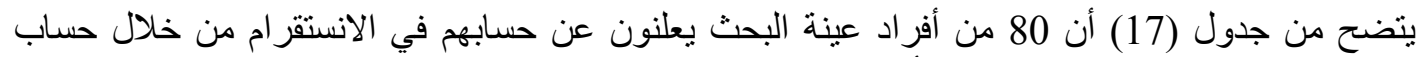

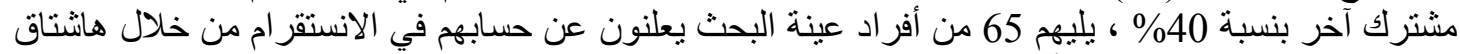

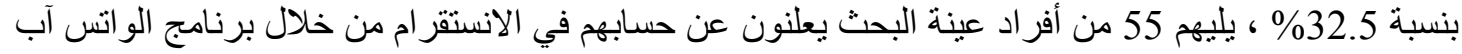

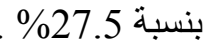

النتائج :

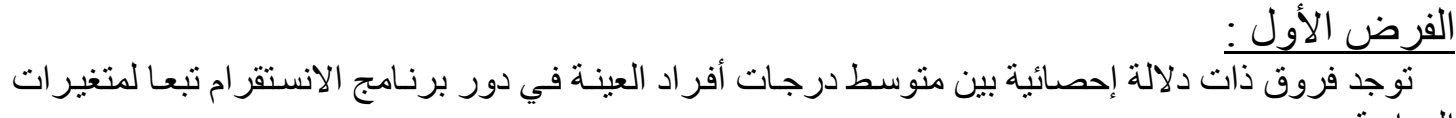
الدر اسة.

اللتحقق من هذا الفرض تم تطبيق اختبار (ت) ، وحسـاب تحليل التباين لارجات أفر اد العينة في دور برنامج

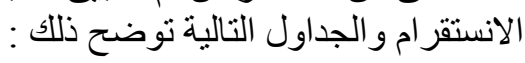

جدول (18) الفروق في متوسط درجات أفر اد العينة في دور برنامج الانستقر ام تبعا لمتغير الجنس

\begin{tabular}{|c|c|c|c|c|c|c|}
\hline الدلالة & قيمة (ت) & الحرجية & العينة & الالنحرياري & الحسابي & الجنس \\
\hline \multirow{2}{*}{ لدال عند الإناث 0.01} & \multirow{2}{*}{11.590} & \multirow{2}{*}{198} & 74 & 1.235 & 17.789 & ذكر \\
\hline & & & 126 & 3.621 & 30.358 & أنثي \\
\hline
\end{tabular}

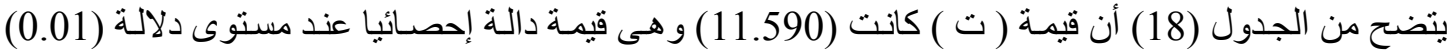

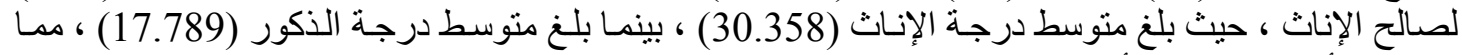

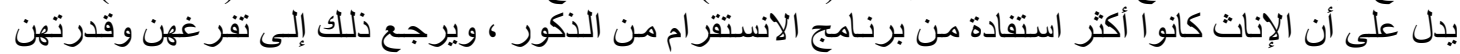
للممارسة المهار ات اليدوية أكثر من الذكور وكثرة ساعات المثات المتابعة و المشاركة لكل جديد في برنامج الانستقر ام. 


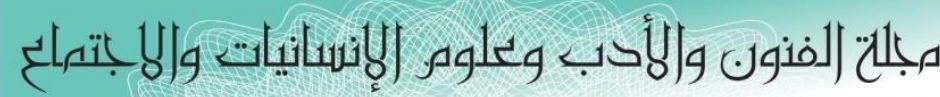
Journal of Arts, Literature, Humanities and Social Sciences

ISSN online: 2414 - 3383

ISSN print: 2616 - 3810

\section{العدد (42) أيلول - سبتمبر 2019}

جدول (19) الفروق في متوسط درجات العينة في دور برنامج الانستقر ام تبعا لمتغير الحالة الاجتماعية

\begin{tabular}{|c|c|c|c|c|c|c|}
\hline 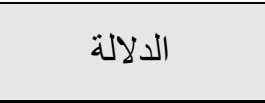 & قيمة (ت) & الحرية & العينة ل & الالحياري & الحسابي & الحالة الاجتماعية \\
\hline \multirow{2}{*}{ لصالح المنزوبين 0.01} & \multirow{2}{*}{12.901} & \multirow{2}{*}{198} & 92 & 3.980 & 35.012 & متزوج \\
\hline & & & 108 & 2.035 & 21.358 & غير متزوج \\
\hline
\end{tabular}

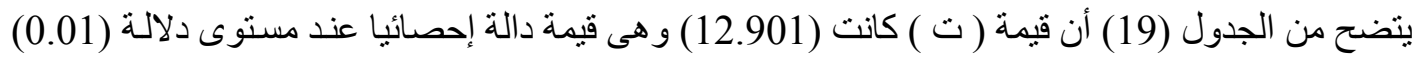

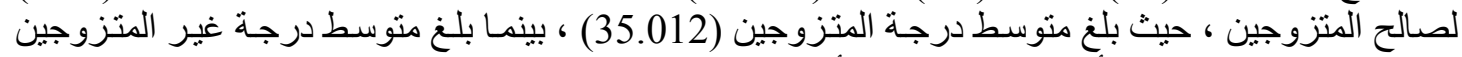

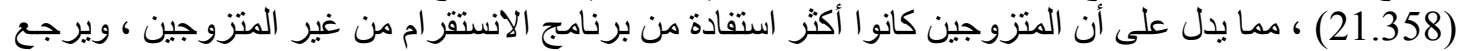

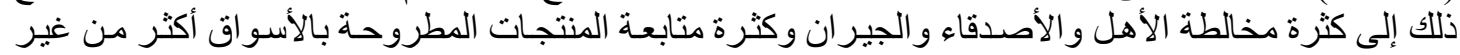

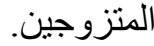

جدول (20) تحليل التباين لارجات أفر اد العينة في دور برنامج الانستقر ام تبعا لمتغير المستوى التعليمي

\begin{tabular}{|c|c|c|c|c|c|}
\hline الدلالة الد & قيمة (ف) & الحرجية & متوسط المربعات & مجموع المربعات & المستوى التعليمي \\
\hline \multirow{3}{*}{0.010} & \multirow{3}{*}{53.957} & 2 & 4673.436 & 9346.873 & بين المجموعات \\
\hline & & 197 & 86.614 & 17062.952 & داخل المجمو عات \\
\hline & & 199 & & 26409.825 & المجموع \\
\hline
\end{tabular}

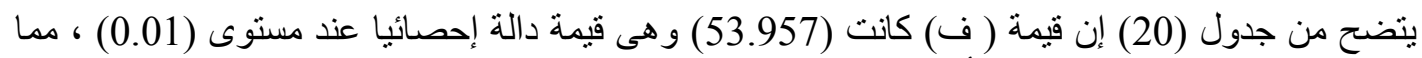

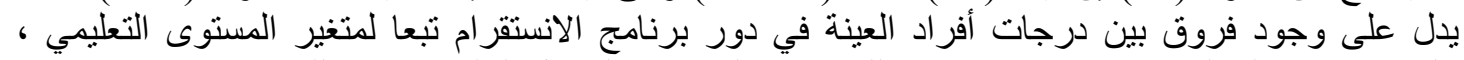

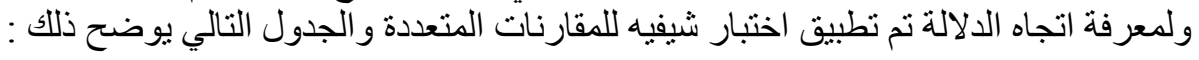

جدول (21) اختبار شيفيه للمقارنات المتعددة

\begin{tabular}{|c|c|c|c|}
\hline م = عالي 29.551 & م = منوسط 22.417 & م = منخفض & المستوى التعليمي \\
\hline & & - & منخفض \\
\hline & - & $* * 6.334$ & متوسط \\
\hline - & $* * 7.134$ & $* * 13.468$ & عالي \\
\hline
\end{tabular}

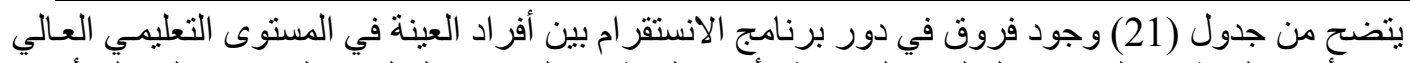

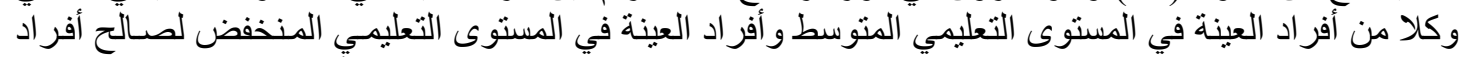

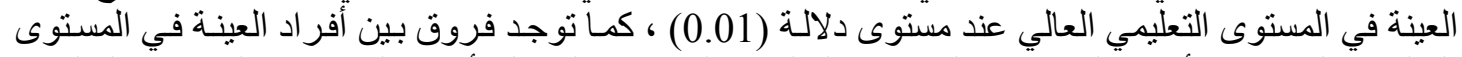

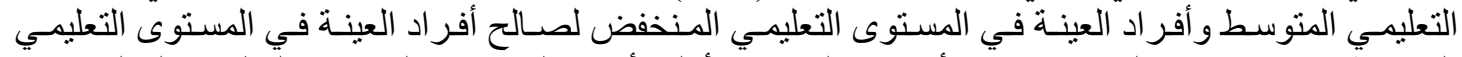

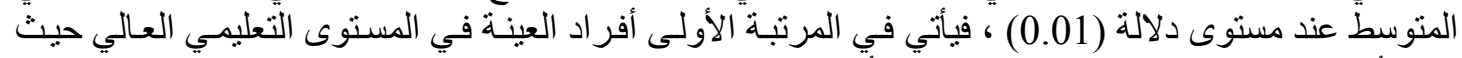

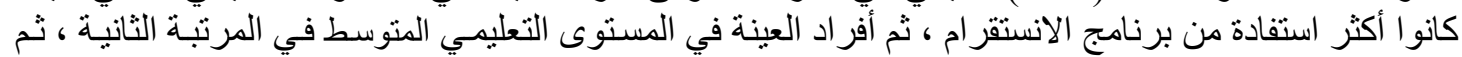

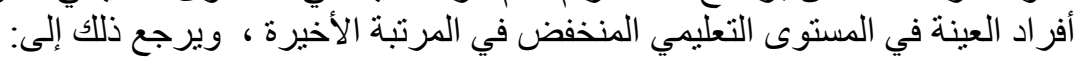

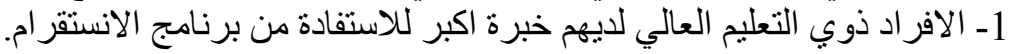

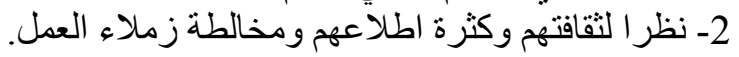




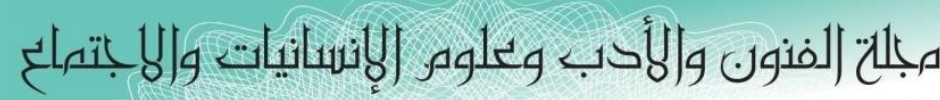
Journal of Arts, Literature, Humanities and Social Sciences

ISSN online: 2414 - 3383

ISSN print: 2616 - 3810

\section{العدد (42) أيلول - لسبتهبر 2019}

جدول (22) تحليل التباين لدرجات أفر اد العينة في دور برنامج الانستقر ام تبعا لمتغير العمر

\begin{tabular}{|c|c|c|c|c|c|}
\hline الدلالة & قيمة (ف) & دالحرجية & منوسط المربعات & مجموع المربعات & العمر \\
\hline \multirow{3}{*}{0.01 دال } & \multirow{3}{*}{47.989} & 2 & 4613.982 & 9227.965 & بين المجمو عات \\
\hline & & 197 & 96.147 & 18940.944 & داخل المجمو عات \\
\hline & & 199 & & 28168.909 & المجموع \\
\hline
\end{tabular}

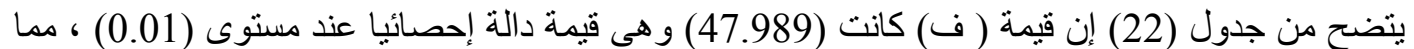

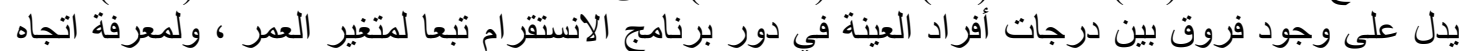

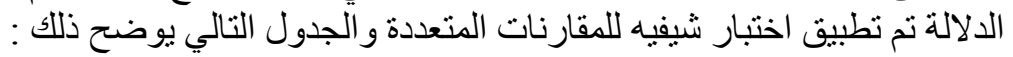
جدول (23) اختبار شيفيه للمقارنات المتعددة

\begin{tabular}{|c|c|c|c|}
\hline من = 30 سنة فأكثر & من 25 سنة لأقل من 30 سنة 25.537 م 25.5 & أقل = 25 سنة 31.444 & 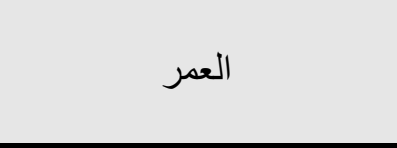 \\
\hline & & - & أقل من 25 سنة \\
\hline & - & $* * 5.907$ & من 25 سنة لأقل من 30 سنة \\
\hline- & $* * 4.916$ & $* * 10.823$ & من 30 سنة فأكثرز \\
\hline
\end{tabular}

يتضح من جدول (23) وجود فروق في دور برنامج الانستقر ام بين أفر اد العينة ذوي السنة العن أقل من 25 سنة سنة

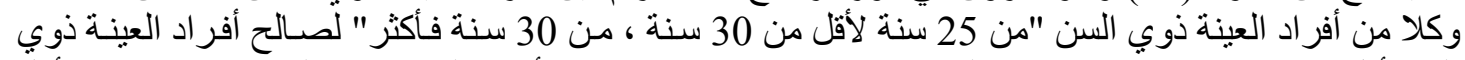

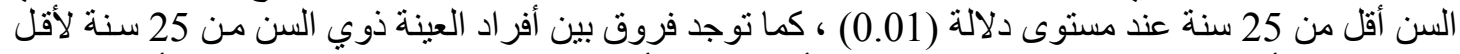

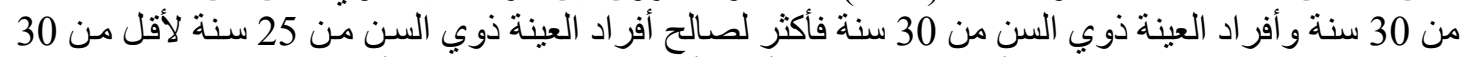

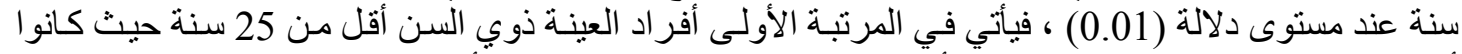

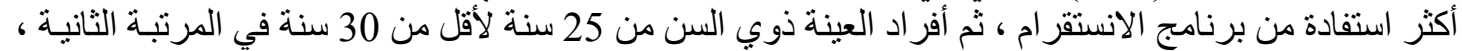

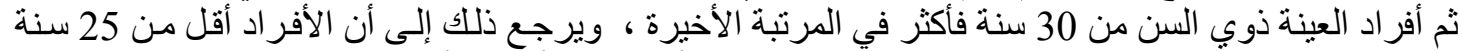

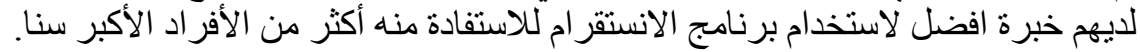

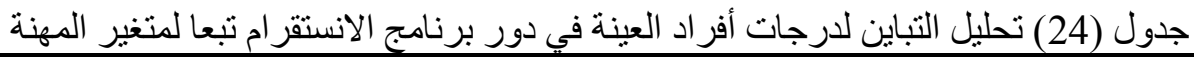

\begin{tabular}{|c|c|c|c|c|c|}
\hline 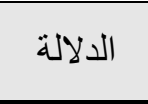 & قيمة (ف) & الحرجية & منوسط المربعات & مجموع المربعات & المهنة \\
\hline \multirow{3}{*}{0.01 دال } & \multirow{3}{*}{37.618} & 3 & 3270.615 & 9811.844 & بين المجموعات \\
\hline & & 196 & 86.944 & 17040.934 & داخل المجمو عات \\
\hline & & 199 & & 26852.778 & المجموع \\
\hline
\end{tabular}

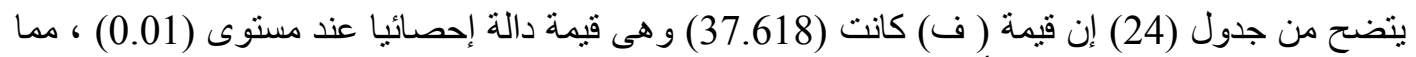

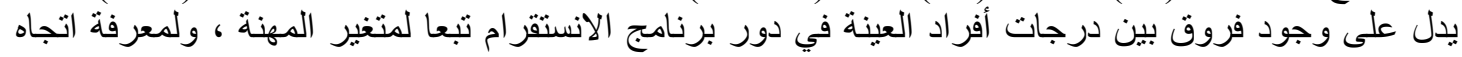

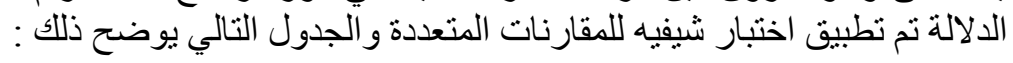




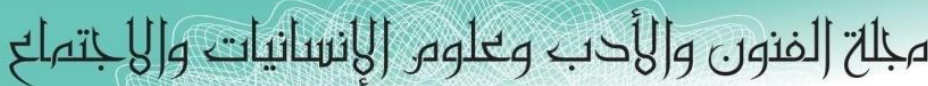
Journal of Arts, Literature, Humanities and Social Sciences

ISSN online: 2414 - 3383

ISSN print: 2616 - 3810

\section{العدد (42) أيلول - سبتهبر 2019}

جدول (25) اختبار شيفيه للمقارنات المتعددة

\begin{tabular}{|c|c|c|c|c|}
\hline طالب / لا بعمل & م = أعمال حرة 21.654 & مُ = قطاع خاص 19.361 & وظبيفة حكو مية & المهنة \\
\hline & & & - & وظيفة حكومية \\
\hline & & - & $* * 8.662$ & قطاع خاص \\
\hline & - & $* 2.293$ & $* * 6.369$ & أعمـال حرة \\
\hline- & $* * 12.413$ & $* * 14.706$ & $* * 6.044$ & طالب / لا يعمل \\
\hline
\end{tabular}

يتضح من جدول (25) وجود فروق في دور برنامج الانستقرام بين أفراد العينة غير العاملين / الطلاب وكلا

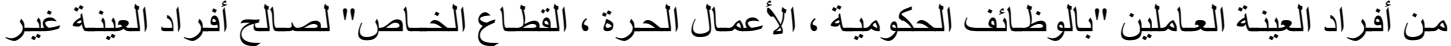

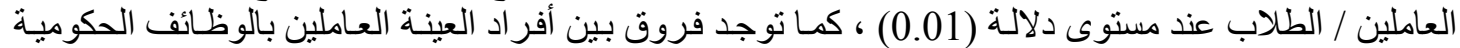

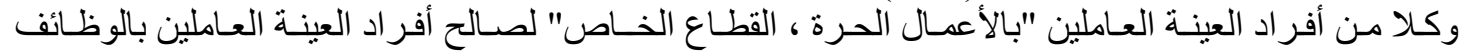

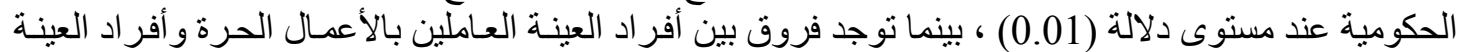

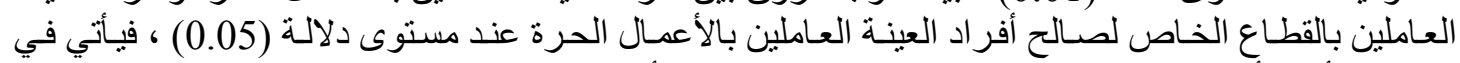

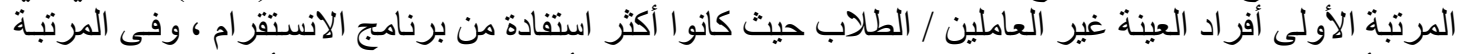

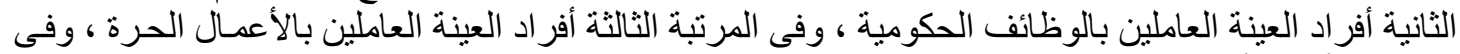

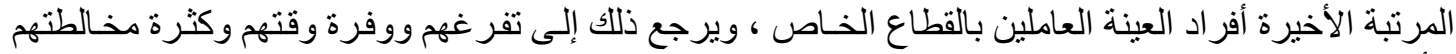

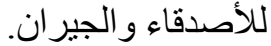

جدول (26) تحليل التباين لدرجات أفراد العينة في دور برنامج الانستقر ام تبعا لمتغير عدد أفر اد الأسرة

\begin{tabular}{|c|c|c|c|c|c|}
\hline الد الدلة & قيمة (ف) & الحرجية & متوسط المربعات & مجموع المربعات & عدد أفراد الأسرة \\
\hline \multirow{3}{*}{0.01 دال } & \multirow{3}{*}{30.064} & 2 & 4354.520 & 8709.040 & بين المجمو عات \\
\hline & & 197 & 144.843 & 28534.046 & داخل المجمو عات \\
\hline & & 199 & & 37243.086 & المجموع \\
\hline
\end{tabular}

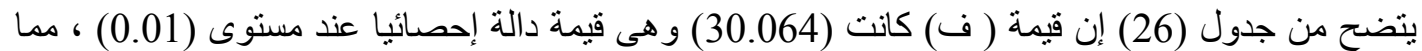

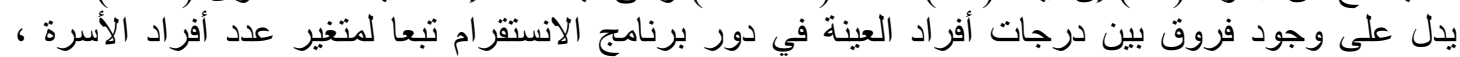

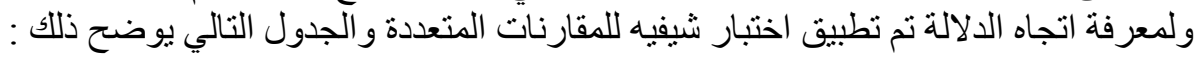
جدول (27) اختبار شيفيه للمقارنات المتعددة

\begin{tabular}{|c|c|c|c|}
\hline من 8 أفر اد فأكثر & 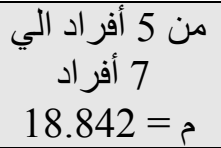 & م = أقل من 5 أفراد & عدد أفر اد الأسرة \\
\hline & & - & أقل من 5 أفر اد \\
\hline & - & $* 2.779$ & من 5 أفر اد الي 7 أفر اد \\
\hline- & $* * 8.678$ & $* * 11.457$ & من 8 أفر اد فأكثر \\
\hline
\end{tabular}

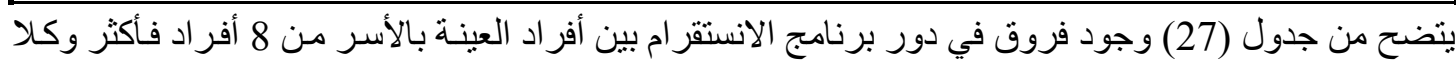

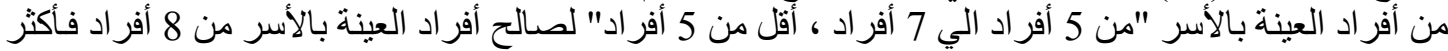

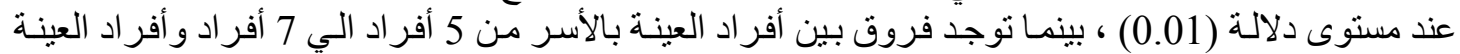

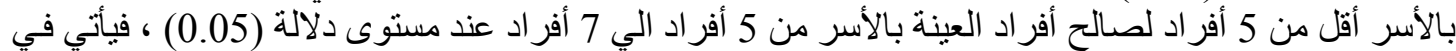

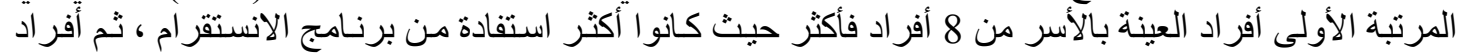

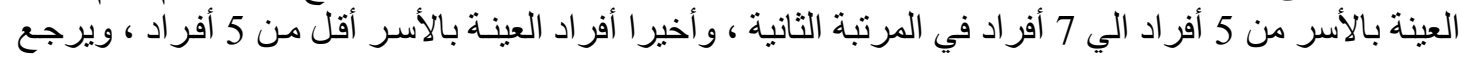




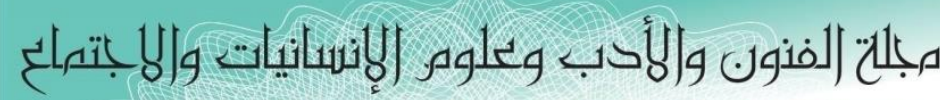
Journal of Arts, Literature, Humanities and Social Sciences

ISSN online: 2414 - 3383

ISSN print: 2616 - 3810

\section{العدد (42) أيلول - سبتمبر 2019}

ذللك إلى أن الأسر ذات العدد الكيير تكون قادرة على تبادل المعلومات و الأفكار من أكثر من فرد داخلها من

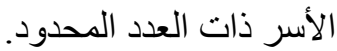

جدول (28) تحليل التباين لدرجات أفر اد العينة في دور برنامج الانستقر ام تبعا لمتغير الدخل الثهري

\begin{tabular}{|c|c|c|c|c|c|}
\hline الدلالة & قيمة (ف) & الحرجية & متوسط المربعات & مجموع المربعات & الدخل الثهري \\
\hline \multirow{3}{*}{0.01 دال } & \multirow{3}{*}{62.061} & 2 & 4741.539 & 9483.078 & بين المجمو عات \\
\hline & & 197 & 76.401 & 15051.094 & داخل المجمو عات \\
\hline & & 199 & & 24534.172 & المجموع \\
\hline
\end{tabular}

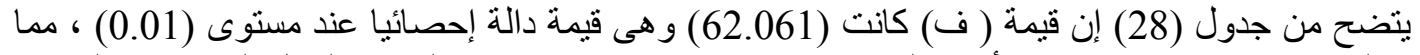

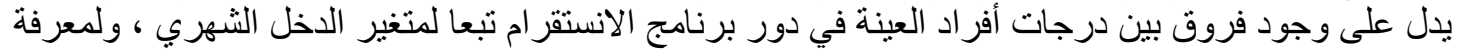

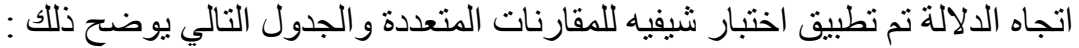
جدول ( 29) اختبار شيفيه للمقارنات المتعددة

\begin{tabular}{|c|c|c|c|}
\hline م = مرتفع 21.381 & 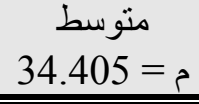 & من منضض 14.477 & الدخل الشهري \\
\hline & & - & منخفض \\
\hline & - & $* * 19.928$ & متوسط \\
\hline- & $* * 13.024$ & $* * 6.904$ & مرتفع \\
\hline
\end{tabular}

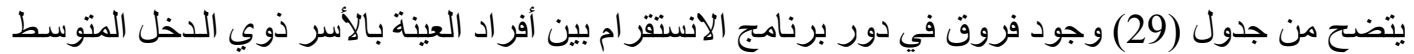

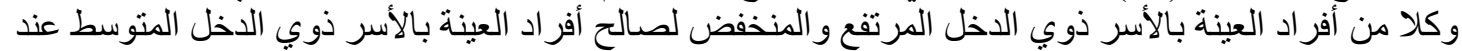

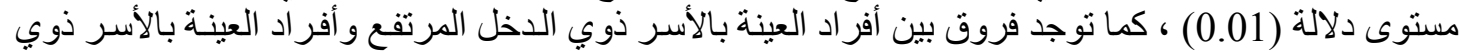

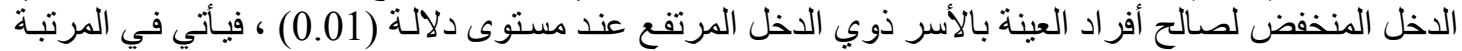

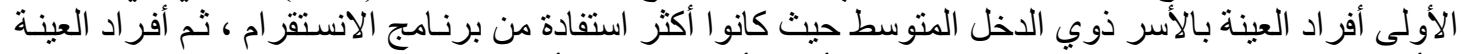

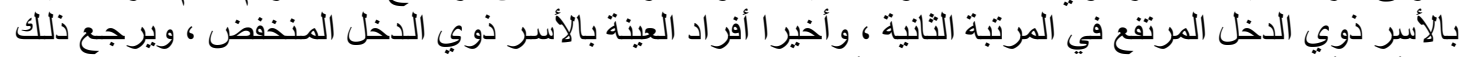

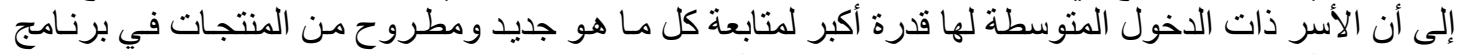
الانستقر ام للاستفادة منها مما يحقق تحسين مستوى دخولهم.

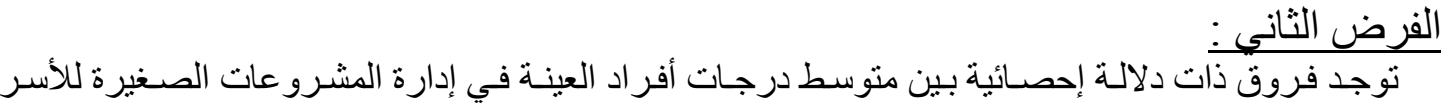
المنتجة تبعا لمتغيرات الدر فاسة.

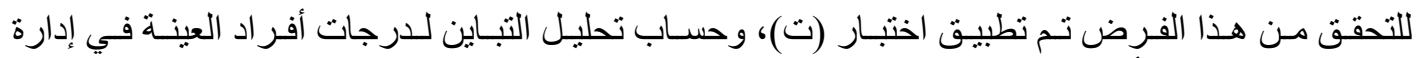

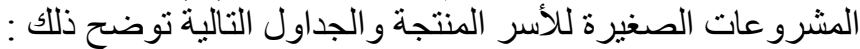

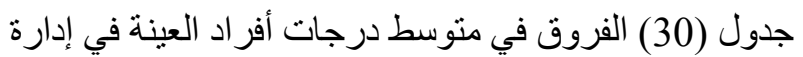

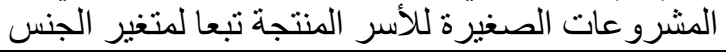

\begin{tabular}{|c|c|c|c|c|c|c|}
\hline الدلالة & قيمة (ت) & الحرجية & العينة & الانحرياري & الحسابي & الجنس \\
\hline \multirow{2}{*}{ دال عند الذكور 0.01} & \multirow{2}{*}{12.035} & \multirow{2}{*}{198} & 74 & 40.321 & 37.531 & ذكر \\
\hline & & & 126 & 2.665 & 24.432 & أنثي \\
\hline
\end{tabular}




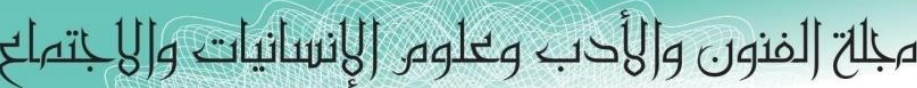
Journal of Arts, Literature, Humanities and Social Sciences

ISSN online: 2414 - 3383

ISSN print: 2616 - 3810

\section{العدد (42) أيلول - سبتهبر 2019}

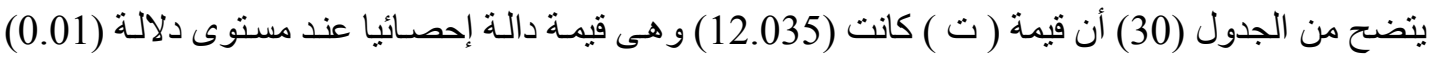

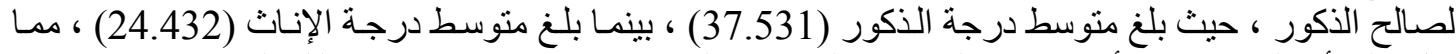

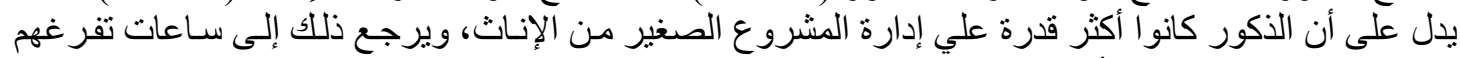

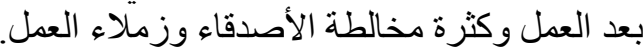

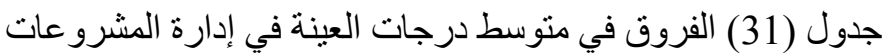

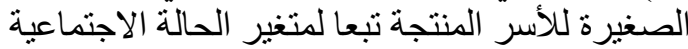

\begin{tabular}{|c|c|c|c|c|c|c|}
\hline الدلالة & قيمة(ت) & الحربية & العينة & الانحر اف & الحسابي & الحالة الاجتماعية \\
\hline \multirow{2}{*}{ لصالح غير المتزوجين 0.01 دال عند } & \multirow{2}{*}{7.111} & \multirow{2}{*}{198} & 92 & 2.087 & 26.571 & منزوج \\
\hline & & & 108 & 3.119 & 33.708 & غير منزوج \\
\hline
\end{tabular}

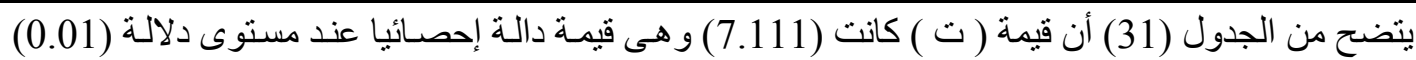

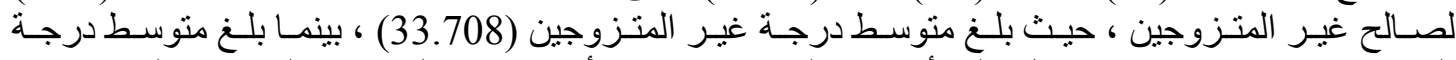

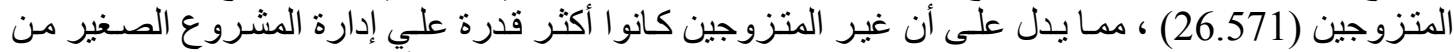

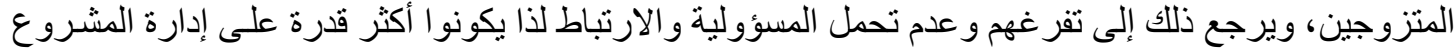

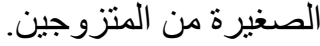

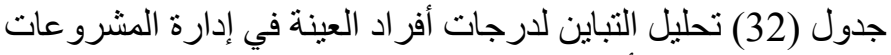

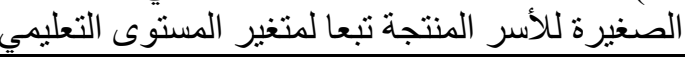

\begin{tabular}{|c|c|c|c|c|c|}
\hline الدلالة & قيمة (ف) & الحرية & متوسط المربعات & مجموع المربعات & المستوى التعليمي \\
\hline \multirow{3}{*}{0.01 دال } & \multirow{3}{*}{43.041} & 2 & 44556.804 & 9113.607 & بين المجموعات \\
\hline & & 197 & 105.871 & 20856.639 & داخل المجمو عات \\
\hline & & 199 & & 29970.246 & المجموع \\
\hline
\end{tabular}

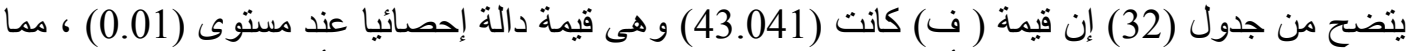

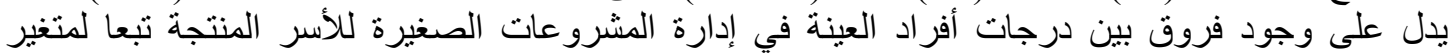

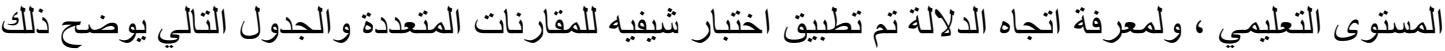

جدول (33) اختبار شيفيه للمقارنات المتعددة

\begin{tabular}{|c|c|c|c|}
\hline م = عالي 35.001 & 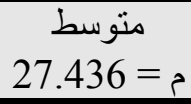 & من = منففض 20.113 & المستوى التعليمي \\
\hline & & - & منخفض \\
\hline & - & $* * 7.323$ & متوسط \\
\hline - & $* * 7.565$ & $* * 14.888$ & عالي \\
\hline
\end{tabular}

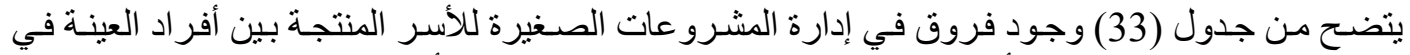

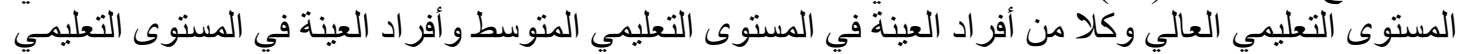

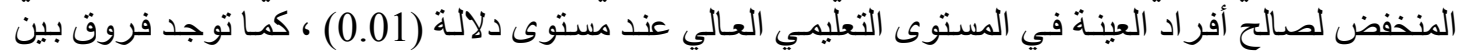

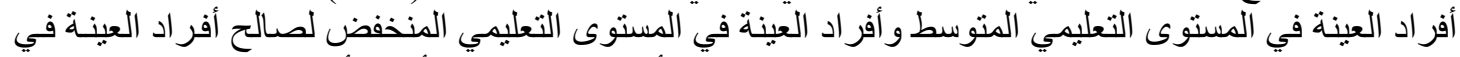

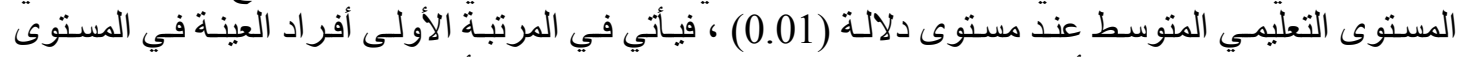

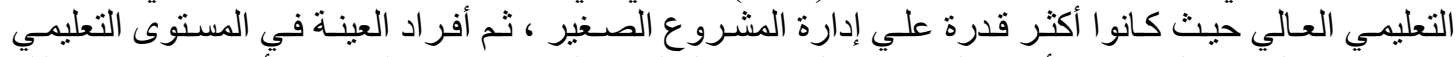

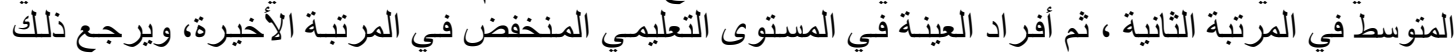




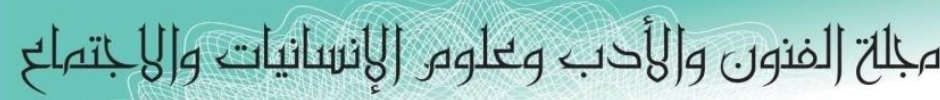
Journal of Arts, Literature, Humanities and Social Sciences

ISSN online: 2414 - 3383

ISSN print: 2616 - 3810

\section{العدد (42) أيلول - سبتهبر 2019}

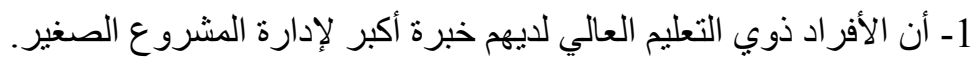

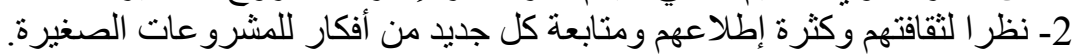

جدول (34) تحليل التباين لدرجات أفراد العينة في إدارة المشرو عات الصغيرة للأسر المنتجة تبعا لمتغير العمر

\begin{tabular}{|c|c|c|c|c|c|}
\hline الدلالة & قيمة (ف) & درجات & متوسط المربعات & مجموع المربعات & العمر \\
\hline \multirow{3}{*}{0.01 دال } & \multirow{3}{*}{34.415} & 2 & 4433.202 & 8866.404 & بين المجمو عات \\
\hline & & 197 & 128.816 & 25376.837 & داخل المجمو عات \\
\hline & & 199 & & 34243.241 & المجموع \\
\hline
\end{tabular}

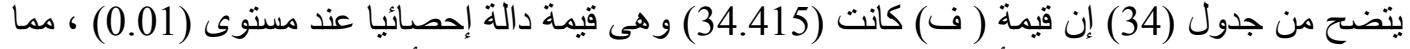

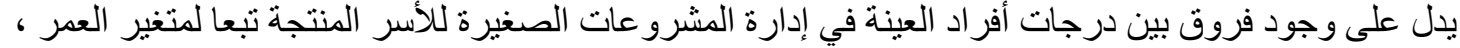

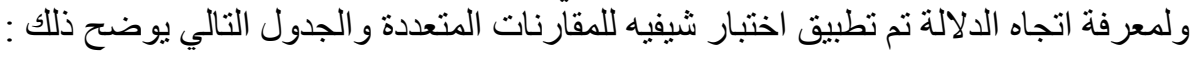

جدول ( 35) اختبار شيفيه للمقارنات المتعددة

\begin{tabular}{|c|c|c|c|}
\hline من = 30 سنة فأكثر & من 25 سنة لأقل من 30 سنة 30 من 30.372 & أقل = 25 سنة 28.135 & 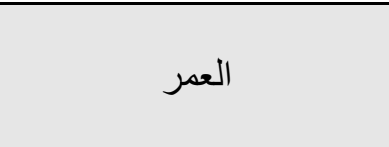 \\
\hline & & - & أَقل من 25 سنة \\
\hline & - & $* 2.237$ & من 25 سنة لأقلَ من 30 سنة \\
\hline - & $* * 7.650$ & $* * 9.887$ & من 30 سنة فأكثر \\
\hline
\end{tabular}

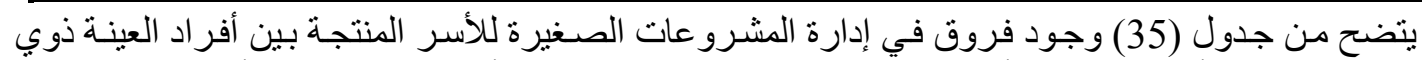

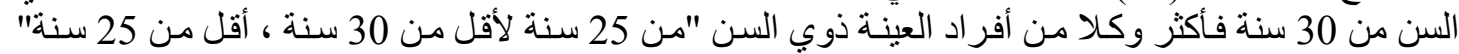

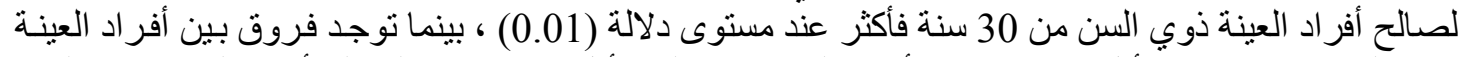

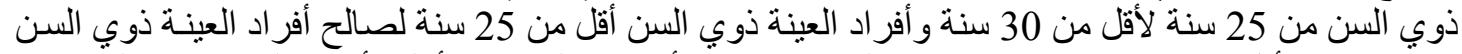

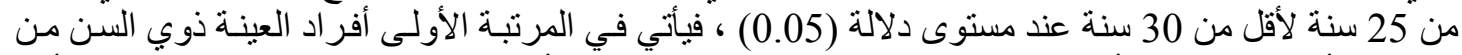

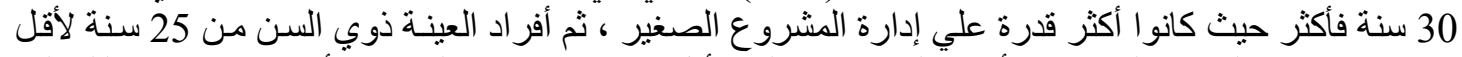

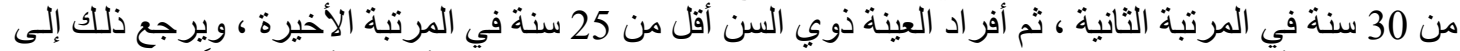
زيادة عمر الأفر اد يزيد من خبرتهم وقدرتهم على إدارة المشروع الصغير من الأفر اد الأصغر سناً.

جدول (36) تحليل التباين لدرجات أفر اد العينة في إدارة المشرو عات الصغيرة للأسر المنتجة تبعا لمتغير المهنة

\begin{tabular}{|c|c|c|c|c|c|}
\hline الدلالة الد & قيمة (ف) & درجات & متوسط المربعات & مجموع المربعات & المهنة \\
\hline \multirow{3}{*}{0.0101} & \multirow{3}{*}{28.495} & 3 & 3171.347 & 9514.042 & بين المجمو عات \\
\hline & & 196 & 111.295 & 21813.774 & داخل المجمو عات \\
\hline & & 199 & & 31327.816 & المجموع \\
\hline
\end{tabular}

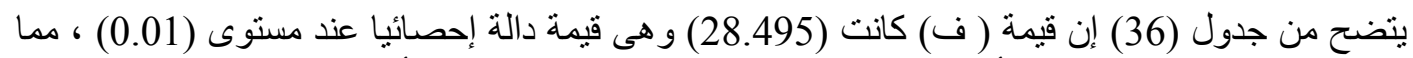

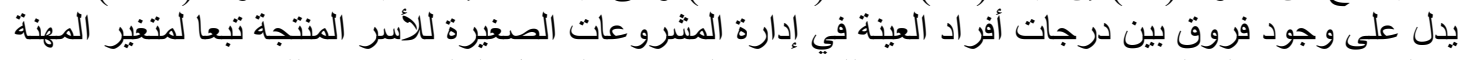

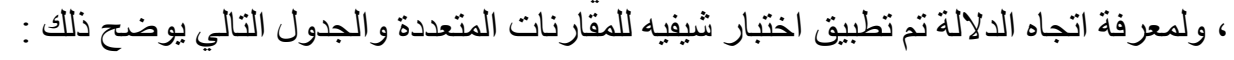




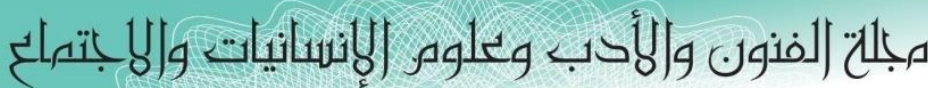
Journal of Arts, Literature, Humanities and Social Sciences

ISSN online: 2414 - 3383

ISSN print: 2616 - 3810

\section{العدد (42) أيلول - سبتهبر 2019}

جدول (37) اختبار شيفيه للمقارنات المتعددة

\begin{tabular}{|c|c|c|c|c|}
\hline طالب / لا يعمل & أعمال حرة = 33.063 & ق = = & و مظبيفة حكومية & المهنة \\
\hline & & & - & وظيفة حكو مية \\
\hline & & - & $* * 11.148$ & قطاع خاص \\
\hline & - & 0.248 & $* * 11.396$ & أعمـال حـرة \\
\hline- & $* * 17.634$ & $* * 17.386$ & $* * 6.238$ & طالب / لا يعمل \\
\hline
\end{tabular}

يتضح من جدول (37) عدم وجود فروق في إدارة المشـرو عات الصـغيرة للأسر المنتجـة بين أفر اد العينـة

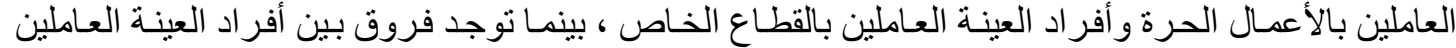

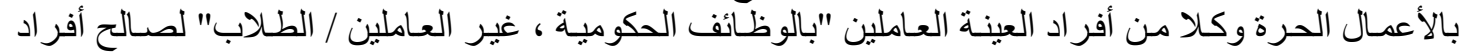

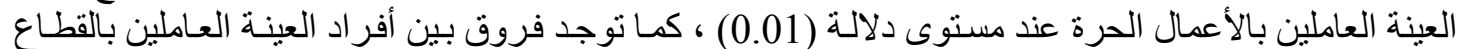

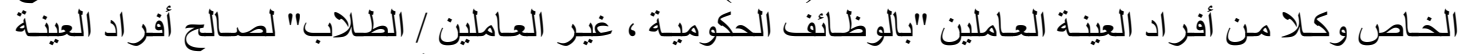

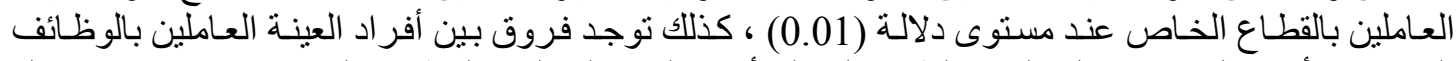

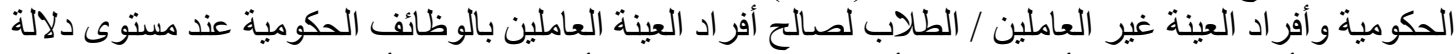

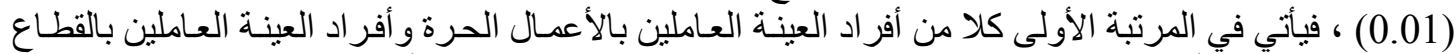

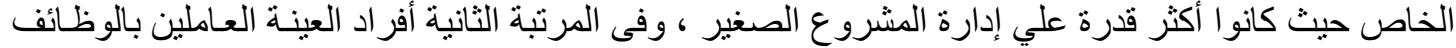

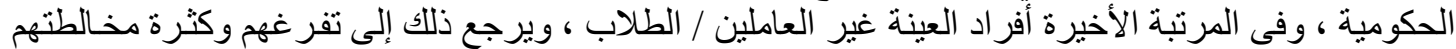
للأصدقاء و الجير ان ووفرة وقتهم أكثر من العاملين بالقطاعات الأخرى.

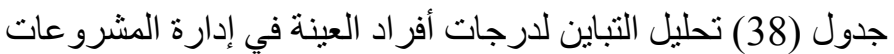

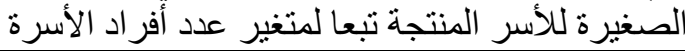

\begin{tabular}{|c|c|c|c|c|c|}
\hline الدلالة & قيمة (ف) & درجات الحرية & متوسط المربعات & مجموع المربعات & عدد أفر اد الأسرة \\
\hline \multirow{3}{*}{0.0101} & \multirow{3}{*}{58.013} & 2 & 4709.095 & 9418.190 & بين المجمو عات \\
\hline & & 197 & 81.174 & 15991.215 & داخل المجمو عات \\
\hline & & 199 & & 25409.405 & المجموع \\
\hline
\end{tabular}

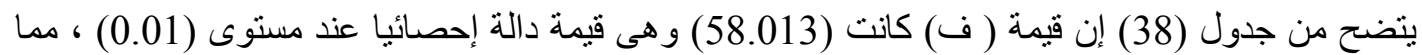

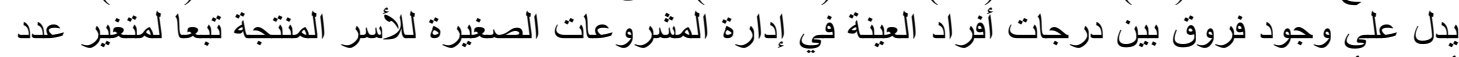

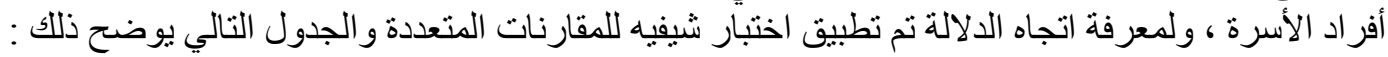

جدول (39) اختبار شيفيه للمقارنات المتعددة

\begin{tabular}{|c|c|c|c|}
\hline من 8 أفر اد فأكثر & من 5 أفراد الي 7 أفراد 7 اد 25.803 من & أقل من 5 أفراد 34.422 أق & عدد أفر اد الأسرة \\
\hline & & - & أقل من 5 أفر اد \\
\hline & - & $* * 8.619$ & من 5 أفر اد الي 7 أفر اد \\
\hline- & $* * 6.367$ & $* * 14.986$ & من 8 أفر اد فأكثر \\
\hline
\end{tabular}

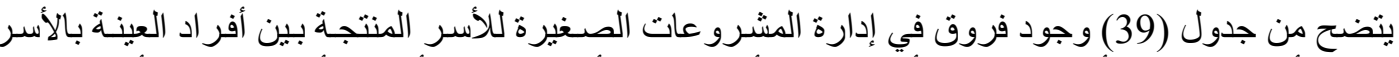

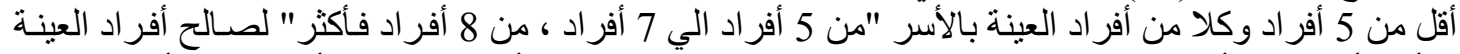

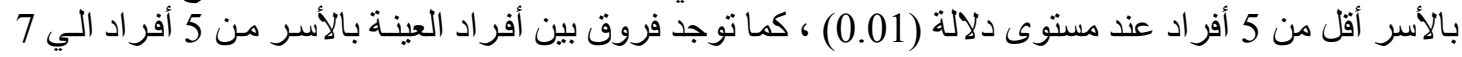




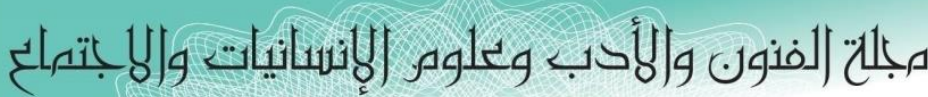
Journal of Arts, Literature, Humanities and Social Sciences

ISSN online: 2414 - 3383

ISSN print: 2616 - 3810

\section{العدد (42) أيلول - لسبتمبر 2019}

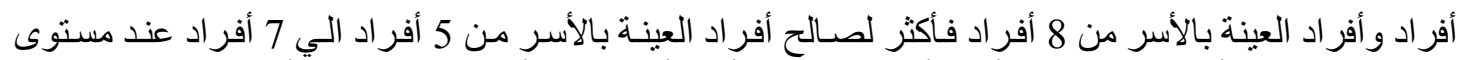

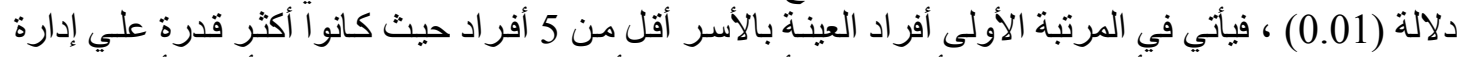

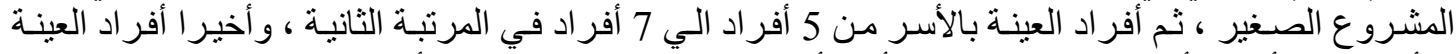

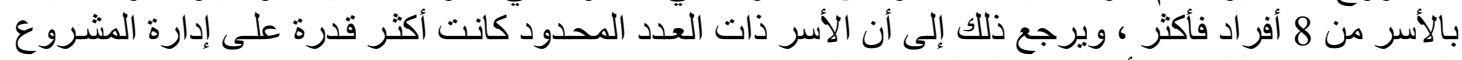

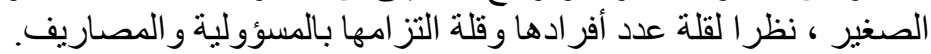

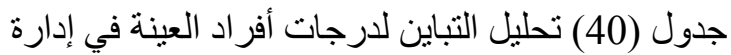

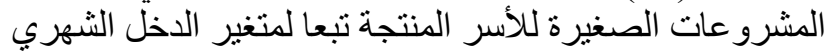

\begin{tabular}{|c|c|c|c|c|c|}
\hline الدلالة الد & قيمة (ف) & الحربية & متوسط المربعات & مجموع المربعات & الدخل الثهري \\
\hline \multirow{3}{*}{0.01 دال } & \multirow{3}{*}{31.103} & 2 & 4374.592 & 8749.183 & بين المجمو عات \\
\hline & & 197 & 140.647 & 27707.441 & داخل المجمو عات \\
\hline & & 199 & & 36456.624 & المجموع \\
\hline
\end{tabular}

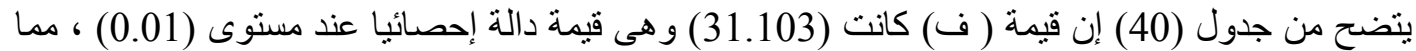

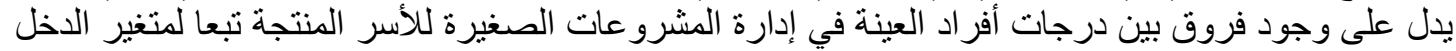

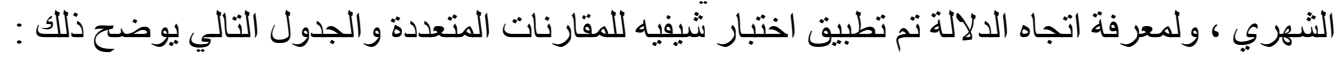
جدول (41) اختبار شيفيه للمقارنات المتعددة

\begin{tabular}{|c|c|c|c|}
\hline م = مرتفع 31.404 & 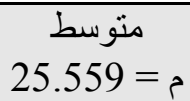 & م = منخفض 23.032 & الدخل الثهري \\
\hline & & - & منخفض \\
\hline & - & $* 2.527$ & متوسط \\
\hline - & $* * 5.845$ & $* * 8.372$ & مرتفع \\
\hline
\end{tabular}

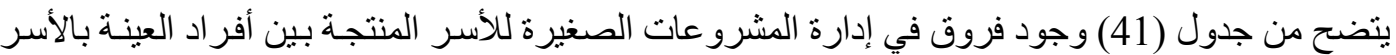

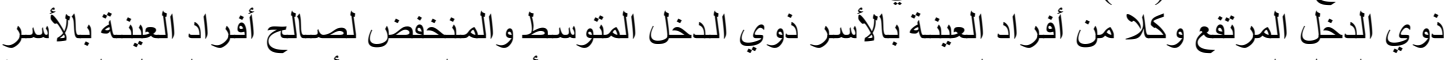

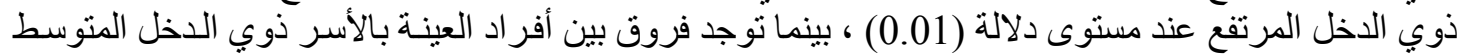

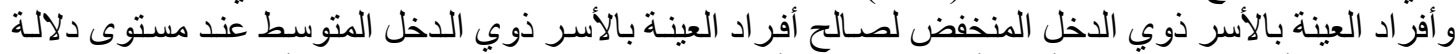

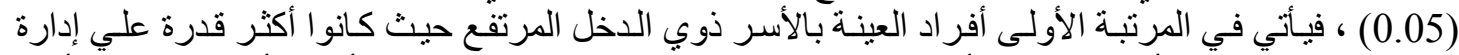

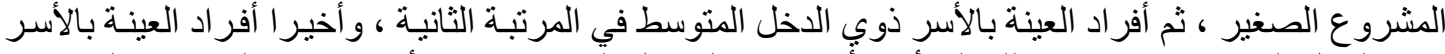

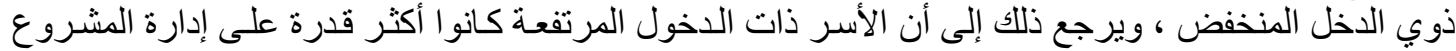

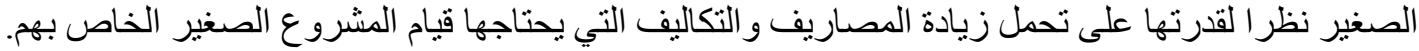

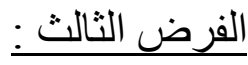
توجد علاقة ارتباطية بين استبيان برنامج الانستقر ام و استبيان المشرو عات الصغيرة للأسر المنتجة .

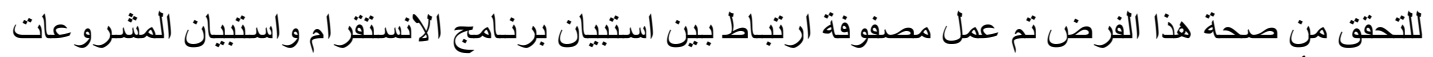
الصغيرة للأسر المنتجة و الجدول التالي يوضح قيم معاملات الارتباط :

جدول (42) مصفوفة الارتباط بين استبيان برنامج الانستقر ام واستبيان المشرو عات الصغيرة للأسر المنتجة المشرو عات الصغيرة للأسر المنتجة $* * 0.889$ برنامج الانستقر ام 


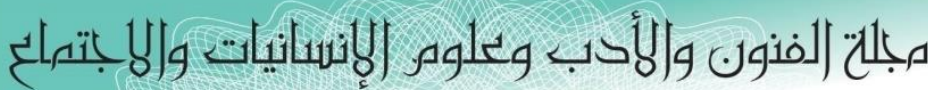

Journal of Arts, Literature, Humanities and Social Sciences

ISSN online: 2414 - 3383

ISSN print: 2616 - 3810

\section{العدد (42) أيلول - سبتهبر 2019}

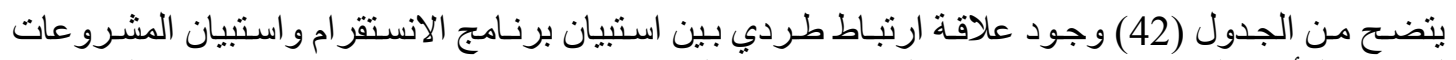

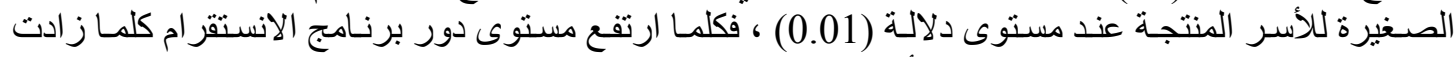

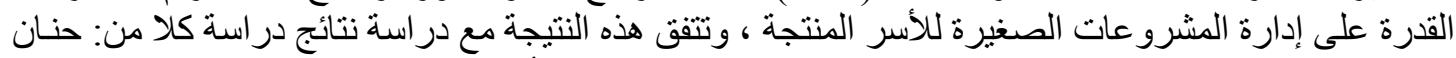

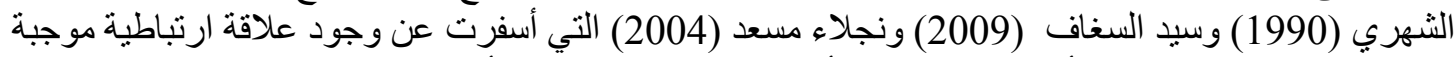

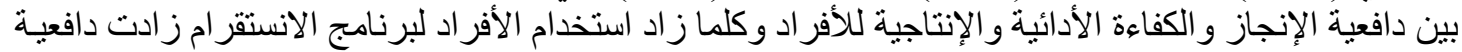
الإنجاز و الكفاءة الأدائية للمشرو عات الصناة الصغيرة.

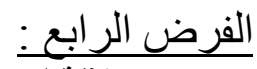
توجد علاقة ارتباطية بين استبيان برنامج الانستقر ام واستبيان المشروعات الصغيرة للأسر المنتجة ومتغيرات الدر اسة. للتحقق من صحة هذا الفرض تم عمل مصفوفة ارتباط بين استبيان برنامج الانستقر ام و استبيان المشرو عات الأنيات

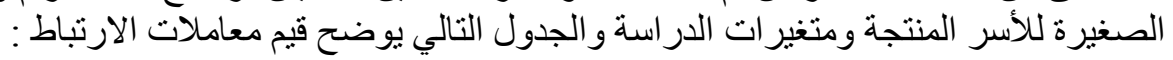

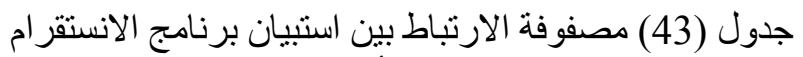

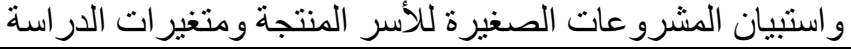

\begin{tabular}{|c|c|c|}
\hline المشروعات الصغيرة المنتجة & برنامج الانستقر ام & المحاور \\
\hline 0.182 & 0.158 & الجنس \\
\hline 0.166 & 0.101 & الحالة الاجتماعية \\
\hline$* * 0.872$ & $* * 0.914$ & المستوى التعليمي \\
\hline$* 0.606$ & $* * 0.793$ & العمر \\
\hline$* * 0.826$ & $* 0.641$ & المهزة \\
\hline 0.136 & 0.191 & عدد أفر اد الأسرة \\
\hline$* * 0.807$ & $* 0.620$ & الدخل الشهري للأسرة \\
\hline
\end{tabular}

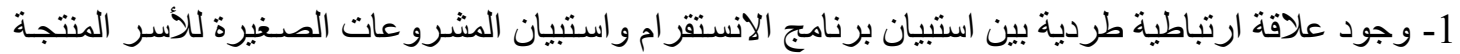

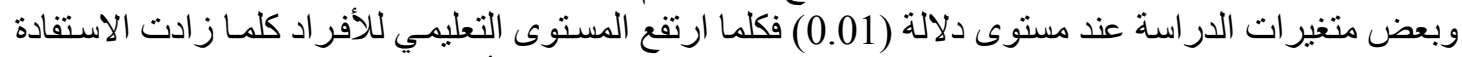

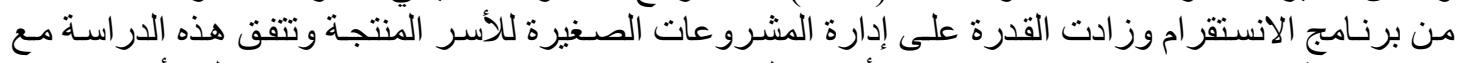

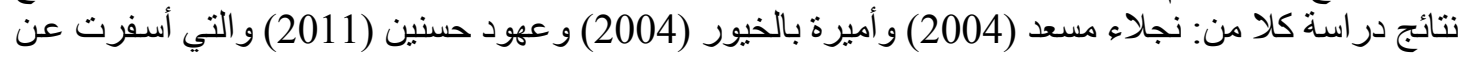
وجود علاقة ارتباطية بين المسنتوى التعليمي وبين القدرة على إدارة المشرو عات الصغيرة عند مسنتوى دلالتة

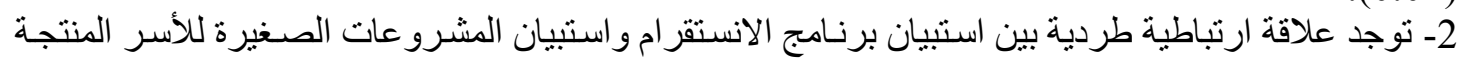

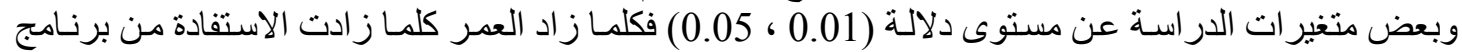

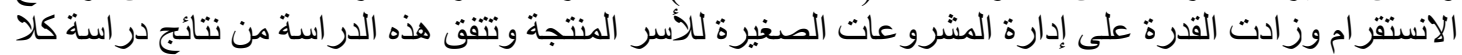

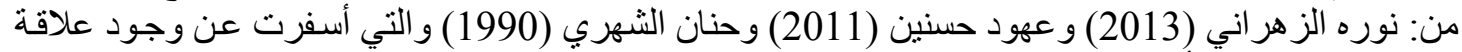

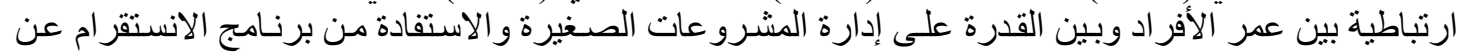

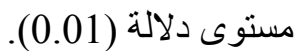

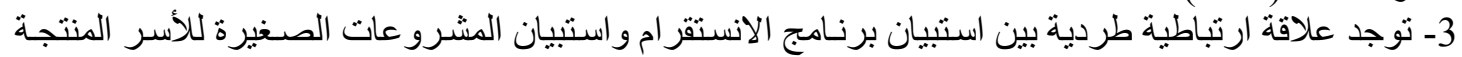

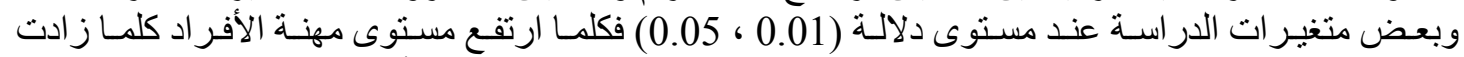

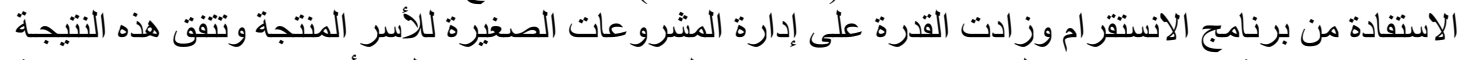

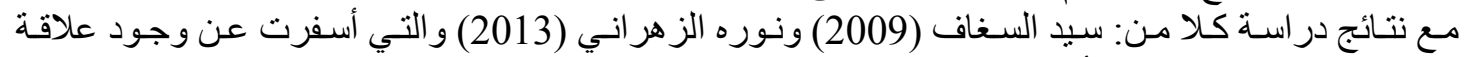
ارتباطية بين مستوى مهنة الأفر اد و القدرة على إدارة المشروعات الصغيرة التهن مستوى دلالة (0.01). 
مبلحة لفنون والأدب وعلوه الإنسانيات و|لبابتهاع

Journal of Arts, Literature, Humanities and Social Sciences

ISSN online: 2414 - 3383

ISSN print: 2616 - 3810

\section{العدد (42) أيلول - سبتهبر 2019}

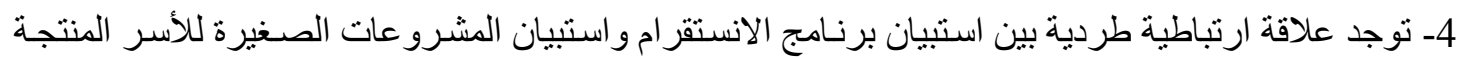

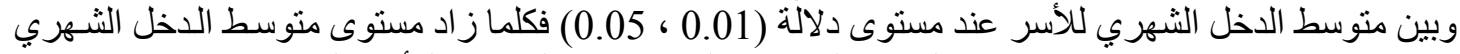

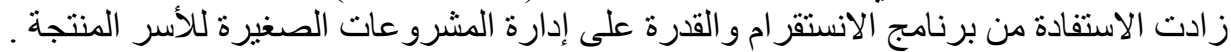

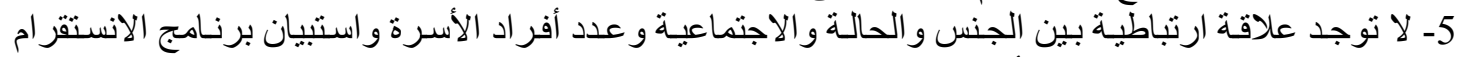
و استبيان المشرو عات الصغيرة للأسر المنتجة . لاطن

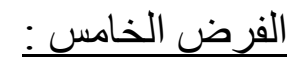

تختلف نسبة مشاركة العو امل المؤثرة على الوعي بدور برنامج الانستقر ام.

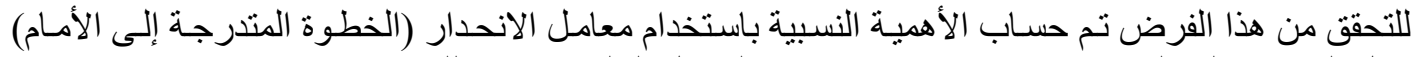

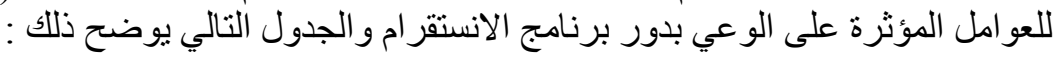

جدول (44) الأهمية النسبية باستخدام معامل الانحدار (الخطوة المتدرجة إلى الأمام)

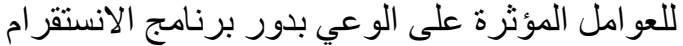

\begin{tabular}{|c|c|c|c|c|c|c|c|c|}
\hline الدلالة & قيمة (ت) & الانحدار & الدلالة & قيمة (ف) & المشاركة & الارنباط & المتغير المستقل & \\
\hline 0.01 & 10.310 & 0.503 & 0.01 & 106.290 & 0.791 & 0.890 & العمر & \\
\hline 0.01 & 7.819 & 0.356 & 0.01 & 61.137 & 0.686 & 0.828 & المستوى التعليمي & : \\
\hline 0.01 & 6.762 & 0.276 & 0.01 & 45.723 & 0.620 & 0.788 & المهنة & \\
\hline 0.01 & 6.118 & 0.221 & 0.01 & 37.429 & 0.572 & 0.756 & الدخل الثهري & \\
\hline
\end{tabular}

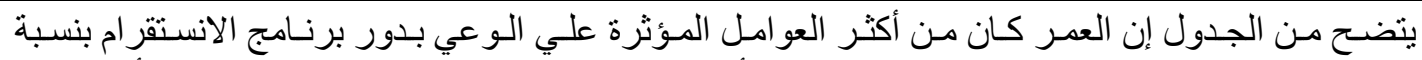

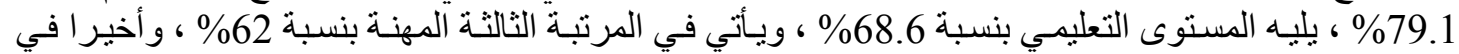

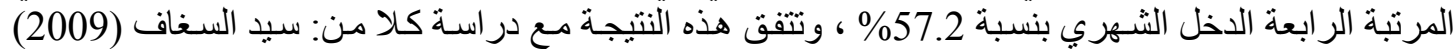

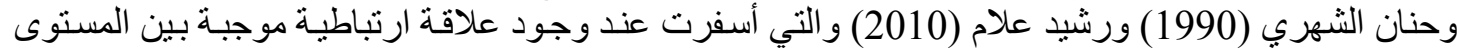

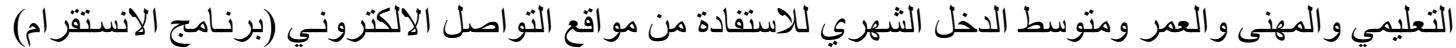
عند مستوى دلالة (0.01).

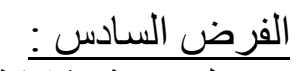

تختلف نسبة مشاركة العو امل المؤثرة على إدارة المشرو عات الصغيرة للأسر المنتجة .

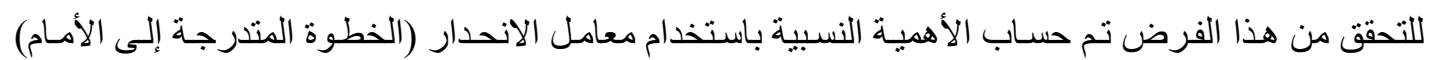
للعو امل المؤثرة على إدارة المشروعات الصغيرة للأسر المنتجة والجدول التهل التالي يوضح ذللك:

جدول (45) الأهمية النسبية باستخدام معامل الانحدار (الخطوة المتدرجة إلى الأمام)

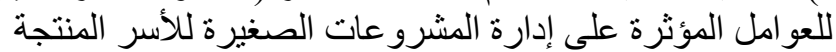

\begin{tabular}{|c|c|c|c|c|c|c|c|c|}
\hline الدلالة الد & قيمة (ت) & الانحدار & الدلالة & قيمة (ف) & المشاركة & الارنباط & المتغير المستقل & E: \\
\hline 0.01 & 8.840 & 0.423 & 0.01 & 78.139 & 0.736 & 0.858 & المستوى التعليمي & \\
\hline 0.01 & 7.112 & 0.304 & 0.01 & 50.580 & 0.644 & 0.802 & الدخل الشهري & \\
\hline 0.01 & 6.417 & 0.247 & 0.01 & 41.177 & 0.595 & 0.772 & العمر - العر & - $\frac{C}{5}$ \\
\hline 0.01 & 5.886 & 0.201 & 0.01 & 34.656 & 0.553 & 0.744 & المهنة & $\underline{E}$ \\
\hline
\end{tabular}




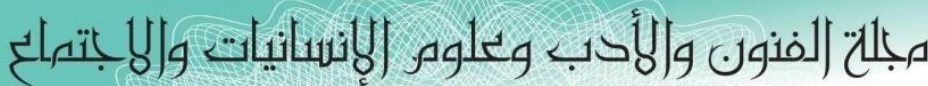

Journal of Arts, Literature, Humanities and Social Sciences

ISSN online: 2414 - 3383

ISSN print: 2616 - 3810

\section{العدد (42) أيلول - سبتهبر 2019}

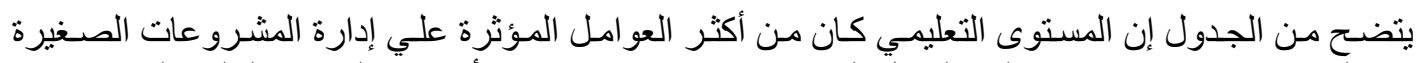

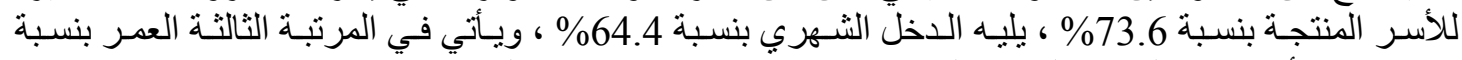

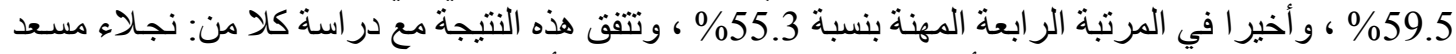

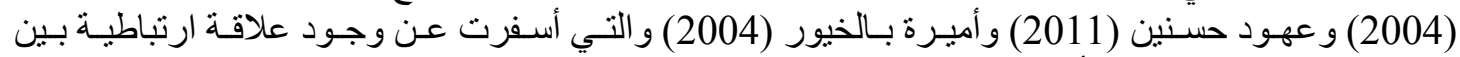

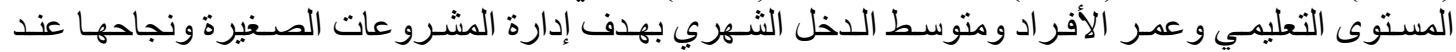
مستوى دلالة (0.01). (0.01).

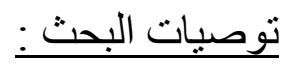

1- العمل على توظيف تكنولو لوبيا الاتصالات الحديثة (برنامج الانستقر ام) لما لذلك من آثار إيجابية عديدة خاصة لدعم المشرو عات الصغيرة الصنيرة الخاصة.

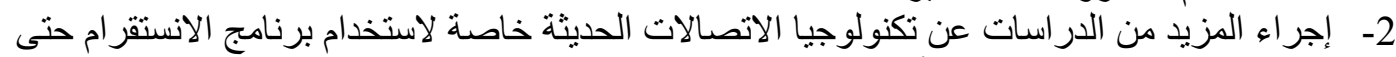

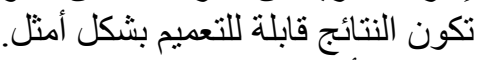
3- تزويد الأفراد بالمعلومات النعيم التي تساعدهم على على المفاضلة بين المنتجات المختلفة من خلال استخدام

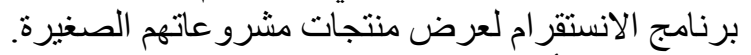

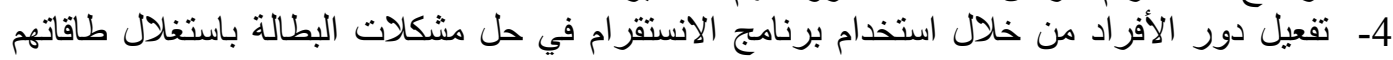

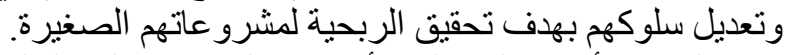

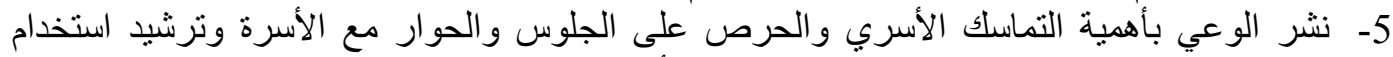

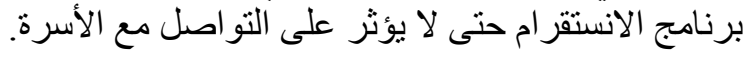

1- الصاوي أنور وخديجة نصر الدين مصطفى وسميرة أحمد قنديل وصلاح على السيد (2000م):

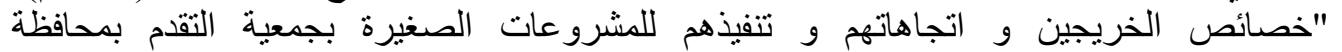

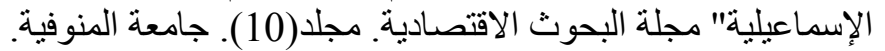

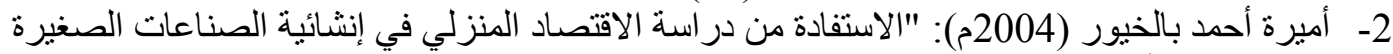

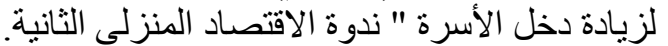

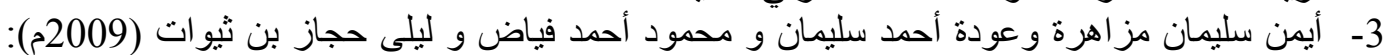

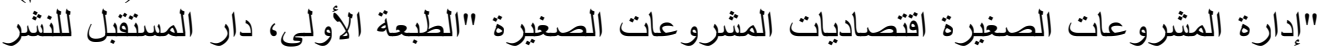

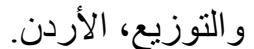
4- بلال خلف السكر الأنة (2006م): "خطط الطوارئ ودور ها في إدارة الأزمات المالية " دار الميسرة للطباعة و النشر، عمان، الأردن.

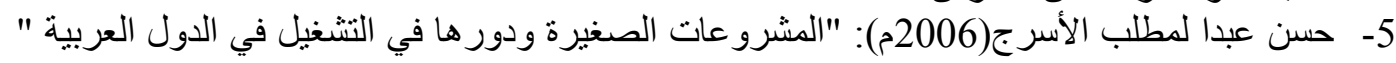
6- حنان بنت شعشوع الثهري (2008م): " أثر استخدام شبكات التواصل الإلكترونية على العلاقات

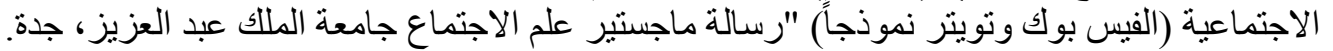

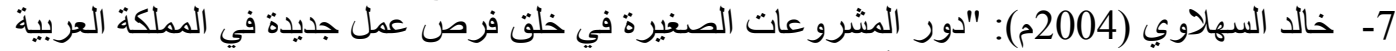

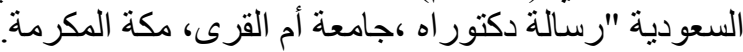

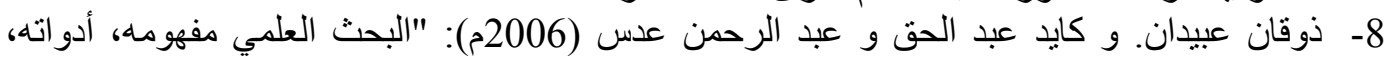
أساليبه" الطبعة الثامنة، دار أسامه للنشر و التوزيد التوزيع، جدة.

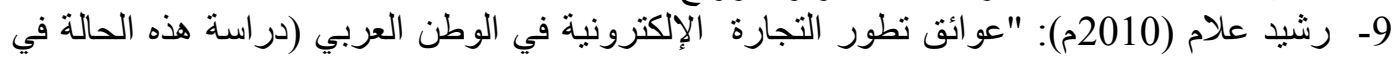

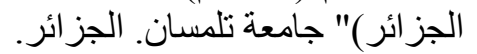
10-زينب الأشوح (2000م): "دامعة الجور النشاط الاقتصادي المنزلي في تحقيق الضوابط الثرعية القانونية

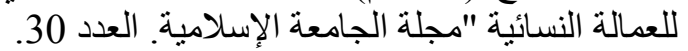

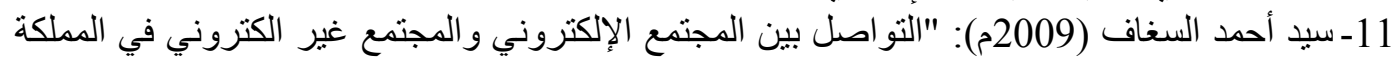
العربية السعودية في 2001-2002" الجامعة الإسلامية باللغة الإنجليزية. 


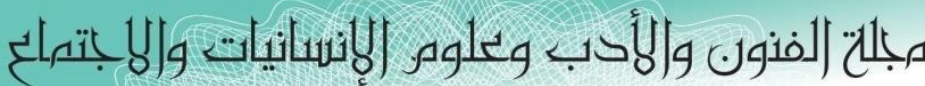

Journal of Arts, Literature, Humanities and Social Sciences

ISSN online: 2414 - 3383

ISSN print: 2616 - 3810

\section{العدد (42) أيلول - سبتمبر 2019}

12- سيد سالم عرفة (2011م): "الجديد في إدارة المشاريع الجديدة "دار الراية للنشر و التوزيع، عمان،

13- شبوطي حكيم ( الاردن. 12008م): "الدور الاقتصادي و الاجنماعي للمؤسسات الصغيرة و المتوسطة "أبحاث اقتصادية و أداريه. جامعه بحي فارس بارس بالمدينة.

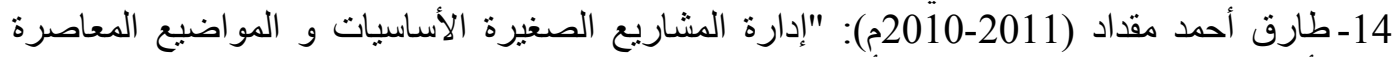
(أدارة المشاريع )" بحث تخر جارف، الأكاديمية العربية البريطانية التعليم العالي.

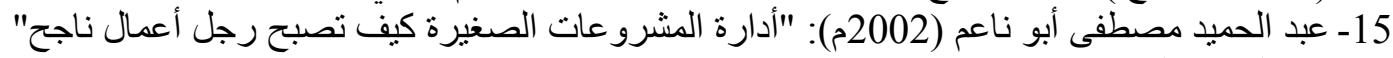

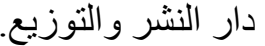

16- عبد العزيز بن عبد الله الخضيري (2006م): "المشروعات الصغيرة والتنمية الاقتصادية "مجلة الاقتصاد، العدد 4634 اعند

17 - عبد الله الصليع (2001م): "الصنداعندات الصنئ الصغيرة في المملكة العربية السعودية "كلبة الإدارة والاقتصاد.

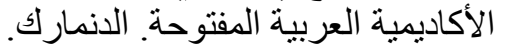

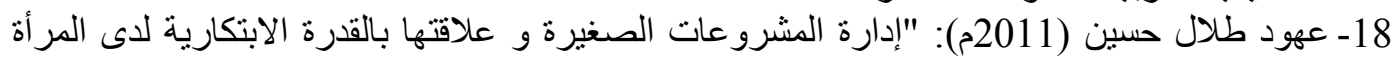

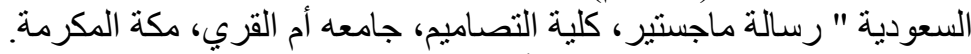

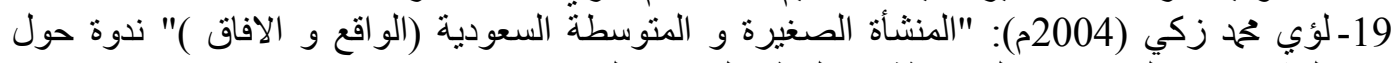

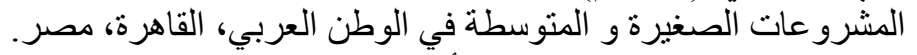

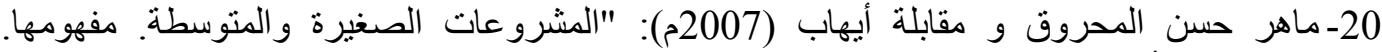

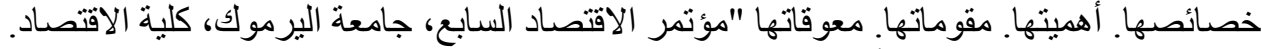

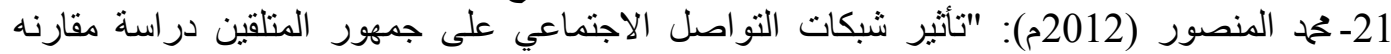

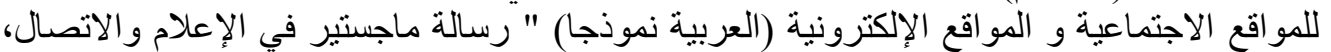

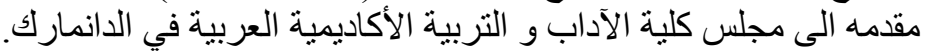

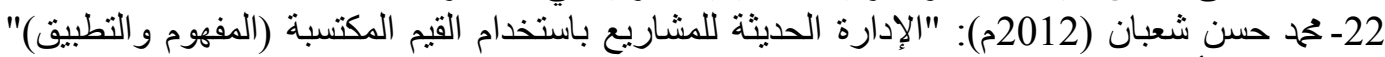

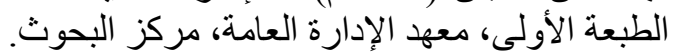

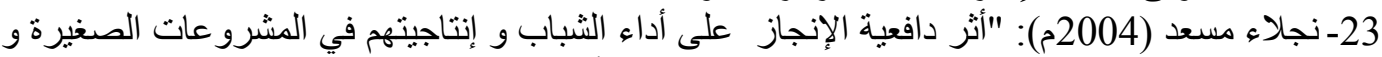

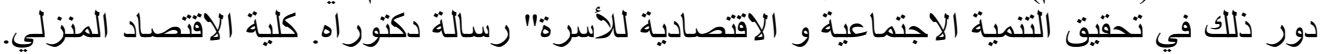
قسم إدارة المنزل. جامعه المنوفية.

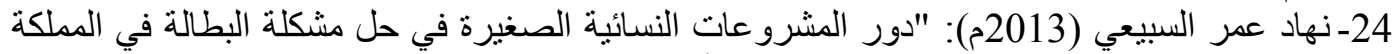

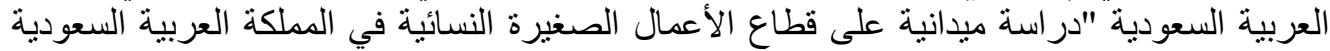

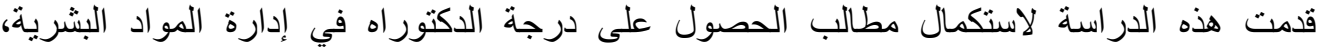
الأكاديمية العربية المفتوحة في الدنمارك، كلية الإدارة و الإقتصاد الداد.

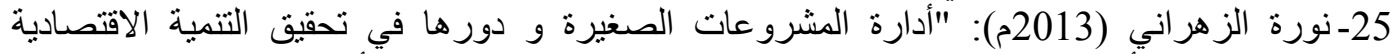

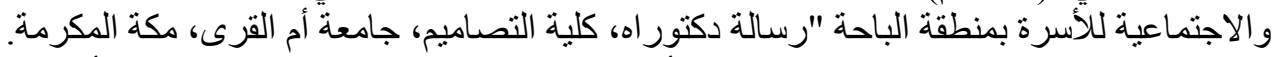

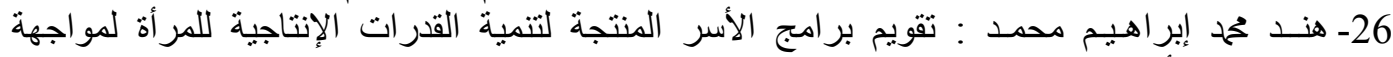

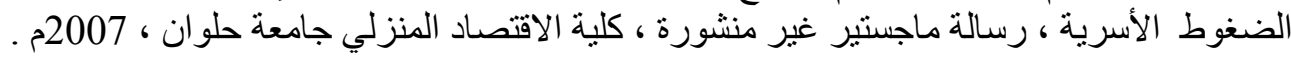

27- Anthony Garman. (2009): "Small Projects Management and Its Relation With

Some Personal Characteristics". North Carolina University.

28-ar. m. wikipedia. org/wiki

29- http: //alwasat. montad mosli. com

30- http: //www. dr-avsha. com

31- https: //theswaggerproj. com/using-instagam-small-/busiess 